\title{
Experiencias artísticas a finales de la última dictadura argentina: entre lo local y lo internacional
}

\section{Artistic experiences at the end of the last Argentine dictatorship: between the local and the international}

\author{
Alejandra Soledad González \\ Instituto de Humanidades, Consejo Nacional de Investigaciones Científicas y Técnicas (CONICET) \\ y Universidad Nacional de Córdoba (UNC)
}

Fecha de recepción: 10 de abril de 2017

Fecha de aceptación: 17 de junio de 2018
Anuario del Departamento de Historia y Teoría del Arte vol. 29-30, 2017-2018, pp. 209-232

ISSN: 1130-5517, eISSN: 2530-3562

http://doi.org/10.15366/anuario2017-2018.29-30.09

\begin{abstract}
RESUMEN
A inicios de la década de 1980, mientras comenzaba el agotamiento de la última dictadura argentina, adquirieron visibilidad algunos grupos de artistas cuyas prácticas materiales y simbólicas cuestionaban al campo artístico y, en ciertas ocasiones, también al macrocosmos social. En este artículo se reconstruye un caso levemente estudiado: la Agrupación para el Desarrollo de Experiencias Visuales. En las primeras tres secciones se indaga la gestación del grupo en la ciudad de Córdoba, dentro del contexto de la política cultural nacional, cuando consiguieron un taller y concretaron una exposición fundacional. Posteriormente, se ensaya una lectura, en clave sociológica de "estructuras de sentimientos", de unas experiencias donde confluyeron: artesanía, cine, escultura, fotografía, instalación, literatura y pintura. Finalmente, se exploran nueve trayectorias de expositores que acreditaban redes locales e internacionales. Para emprender esta investigación se recurrió a un enfoque transdisciplinar de Historia Cultural y al análisis de variados documentos escritos, orales y visuales.
\end{abstract}

\section{PALABRAS CLAVE}

Estrategias artísticas. Dictadura argentina. Intersticios. Década de 1980. Experiencias.

\begin{abstract}
At the beginning of the 1980s, while the exhaustion of the last Argentine dictatorship began, some groups of artists whose material and symbolic practices questioned the artistic field and, in certain cases, the social macrocosm, gained visibility. In this article a slightly studied case is reconstructed: the Grouping for the Development of Visual Experiences. In the first three sections, the gestation of the group in the city of Córdoba is investigated, within the context of national cultural policy, when they achieved a workshop and made a foundational exhibition. Afterwards, a reading is rehearsed, in a sociological key of "structures of feelings", of experiences where they converged: crafts, cinema, sculpture, photography, environment, literature and painting. Finally, nine trajectories of artists accrediting local and international networks are explored. To undertake this research, a transdisciplinary approach to Cultural History was used, as well as the analysis of various written, oral and visual documents.
\end{abstract}

\section{KEY WORDS}

Artistic strategies. Argentine dictatorship. Interstices. 1980s. Experiences. 


\section{Política cultural dictatorial: entre censuras, fomentos e intersticios ${ }^{1}$}

Una de las primeras "huellas"2 documentales que visibilizó detalles sobre la Agrupación para el Desarrollo de Experiencias Visuales (ADEV) fue una noticia publicada a inicios de 1983 en el periódico Tiempo de Córdoba. Allí se reseñaba que "la Municipalidad había cedido" al grupo un "gran espacio" de trabajo gratuito dentro una institución oficial, a saber: el subsuelo del Centro Cultural Alta Córdoba (CCAC) 3 . Para aproximarnos a algunos hilos que enlazaban factores condicionantes generales con estrategias particulares conviene sintetizar los dos sentidos adjudicados por el gobierno dictatorial a la palabra "Cultura" (con mayúscula). En sentido amplio, se usaba para designar un modo de vida nacional que, desde la visión hegemónica, definía a la identidad cultural argentina. En sentido restringido, hacía referencia a las obras y prácticas que surgen como producto de la actividad intelectual, espiritual y estética (particularmente, el arte).

El imaginario oficial defendía desde el Golpe de Estado de 1976 (aunque recuperando ideas anteriores de la Guerra Fría) la existencia de una "guerra integral contra el comunismo", la cual, desde su visión, se libraba tanto en planos materiales como "espirituales" . Así, se desarrolló, a nivel nacional, una "política cultural"' dual donde se mixturó una faceta destructiva (que hizo "desaparecer" a aquellas personas e ideas consideradas "subversivas") con una faceta constructiva (que proclamaba la refundación de un orden social tradicional cimentado en la trilogía de valores de "Dios, Patria y Familia") ${ }^{6}$. El año 1980, en la ciudad de Córdoba, implicó una bisagra ya que el diagnóstico bélico oficial celebraba la "victoria armada sobre el marxismo", en diarios como La Voz del Interior; pero paralelamente advertía sobre la amenaza latente en el plano cultural"

Ese contexto torna entendible que en la coyuntura cordobesa 1980-1983 hayan proliferado políticas culturales que promovieron nuevas instituciones y eventos artísticos; entre los casos paradigmáticos sobresalen los Centros Culturales barriales ${ }^{8}$. Estos últimos formaron parte de un programa dirigido por el

\footnotetext{
1 Una primera versión de este trabajo fue presentada como ponencia en la Mesa 15 (Prácticas artísticas en tiempos de dictadura: abordajes para complejizar la idea de resistencia cultural) del IX Seminario Internacional Politicas de la Memoria, 40 años del golpe cívico-militar. Noviembre de 2016, Buenos Aires, Argentina. Agradezco los comentarios que, en ese marco, me brindaron la Dra. Ana Longoni y la Dra. María Aimaretti. En este artículo se ofrece una versión revisada e inédita.

2 Carlo Ginzburg, El hilo y las huellas: lo verdadero, lo falso, lo ficticio, Buenos Aires, FCE, 2006.

3 M.U. [Marta Uriarte], "Plástica. La necesidad de nuevas propuestas", Tiempo de Córdoba, 24 de enero de 1983 , p. 11.

${ }^{4}$ Cf. Hernán InVERNIZZI y Judith Gociol, Un golpe a los libros. Represión a la cultura durante la última dictadura militar, Buenos Aires, Eudeba, 2002.

5 Toby Miller y George Yúdice, Politica cultural, Barcelona, Gedisa. 2004.

${ }^{6}$ El trabajo de Quiroga permite diferenciar cuatro fases dentro de la última dictadura argentina: 1) Legitimación (1976-mediados de 1978), donde la presidencia de facto del General Videla recibe apoyo social; 2) Deslegitimación (1978-1979), cuando dicho consenso comienza a resquebrajarse; 3) Agotamiento, comprende el último año gubernativo de Videla y dos breves coyunturas: el ensayo aperturista del General Viola (1981) y la gestión del General Galtieri (fines de 1981-mediados de 1982) cuando se desarrolla la Guerra de Malvinas. La crisis comenzada en 1980 (cuando se precipitan las tensiones sociales acumuladas en años precedentes y se vislumbra la vulnerabilidad del sistema financiero) irá acrecentándose. Así, se desemboca en la siguiente fase: 4) Descomposición (mediados de 1982-finales de 1983). Etapa del derrumbe durante la presidencia del General Bignone, donde confluyen las disidencias internas en las FFAA, la derrota en la Guerra de Malvinas y la crisis económica. Hugo QuIROGA, El tiempo del "Proceso". Conflictos y coincidencias entre políticos y militares, Rosario, Fundación Ross, 2004, p. 197-ss.

7 "El gobernador de la Provincia, general Adolfo Sigwald, iniciando diálogo político con los doctores Boixadós, Caturelli y Rossetti", La Voz del Interior, 31 de mayo de 1980, p. 9.

${ }^{8}$ La ciudad de Córdoba fue fundada en el siglo XVI por colonizadores españoles, siendo reconocida en la vigésima centuria por su desarrollo industrial y cultural. Es llamada La docta en alusión a que su universidad, creada en 1613, es la más antigua del país. También se la denomina Ciudad de las campanas en referencia a las múltiples iglesias que emergen en su suelo. Junto con esas representaciones tradicionalistas, a lo largo del siglo XX irrumpen en ella, entre otros procesos, dos acontecimientos en torno a los cuales se le asignó el rótulo internacional de revolucionaria: la Reforma Universitaria (1918) y el levantamiento obrero-estudiantil conocido como el Cordobazo (1969). La efervescente actividad político-cultural entre finales de los años ' 60 y comienzos de los '70 difundieron el calificativo de Córdoba combativa. Esta ciudad fue uno de los espacios clave de implantación de la última dictadura. Después de Buenos Aires (capital del país), disputaba con la ciudad de Santa Fe el segundo puesto en cantidad de población. Entre los estudios de Historia Reciente sobre los alcances de la dictadura argentina en y desde Córdoba, puede consul-
} 
arquitecto Miguel Roca (Secretario de Obras Públicas de la provincia), donde se mixturaban principios de descentralización y refuncionalización de edificaciones antiguas, como los edificios de ex-mercados. En ese marco, se inauguraron Centros Culturales en distintos barrios citadinos: Güemes (1980), San Vicente (1981), Alta Córdoba (1981) y General Paz (1982). El discurso dictatorial, en revistas oficiales como la Guía de Córdoba Cultural, los definía como una "irradiación" desde el centro histórico-comercial hacia las periferias, una "provisión masiva de alimentos espirituales y un rescate para la cultura de sitios en desuso"9.

Esa hipótesis corroborada para Córdoba encuentra puntos de contacto con otras investigaciones sobre los alcances de la dictadura cívico-militar en la capital del país, Buenos Aires. Al respecto, Longoni sostiene:

En aquellos años negros se produjo, y mucho: existió una variada y contradictoria trama de producciones artísticas que van desde las políticas oficiales (que no se restringieron a la censura y la persecución) y sus vínculos con la industria cultural [...] hasta aquellas diversas (y arriesgadas) estrategias de producción, circulación y asociación". Así, en lugar de pensar en unívocos consensos y resistencias, conviene comprender que, en una coyuntura donde se sobrevivía "entre el terror y la fiesta", se produjeron fluctuaciones, "fisuras y alternativas, espacios de negociación, riesgo y confrontación ${ }^{10}$.

Más allá (y en el medio) de los objetivos gubernativos, el estudio de los Centros Culturales de Córdoba demuestra que allí no solo se reproducían los cánones estético-éticos del régimen, sino que fueron espacios donde se habilitaron estrategias creativas que tensionaban a lo hegemónico. Tanto en el plano individual como en el colectivo, la concesión y la apropiación de un lugar como el sótano del CCAC para el trabajo artístico de ADEV viabilizó diversas micro-políticas. Algunas posibilitaron disidencias simbólicas ante el mandato oficial de "crear belleza", una regla que en artes plásticas era asociada con particulares tradiciones y jerarquías ${ }^{11}$. Entre ellas, en fuentes oficiales encontramos visibilizadas, en orden decreciente de importancia, a diversas sub-disciplinas: pintura, escultura, dibujo, grabado, artesanía. En torno a las corrientes estilísticas, el gusto dictatorial recaía en tendencias figurativas "neo" que resignificaban "ismos" de los siglos XIX y XX; en grado decreciente de importancia los eventos oficiales evidenciaban: clasicismo, impresionismo, surrealismo y expresionismo. Pero no se trató de un sistema monolítico fijo sino de fluctuantes tendencias "dominantes, residuales y emergentes"12; donde, desde circuitos estatales y alternativos, algunos artistas elaboraron propuestas estético-políticas que aportaron disrupciones al "campo" artístico y al macrocosmos social13.

Además de posibilitar la producción de obras que se alejaban del gusto dictatorial, los Centros Culturales son calificados, por la mayoría de los entrevistados, como un tipo de "refugios" ante un contexto de "locura, violencia, tristeza, temor, (auto)censura y parálisis"14. Si en Buenos Aires algunos espa-

tarse: AA.VV., Número Especial: 40 Aniversario del Golpe Cívico-Militar de 1976, Revista Alfilo (2016) Área de Comunicación Institucional de la Facultad de Filosofía y Humanidades, Universidad Nacional de Córdoba. [en línea], http://www.ffyh.unc.edu.ar/alfilo/especial-24marzo/ [Consulta: 1 de mayo de 2016].

9 “Inauguración del Centro Cultural 'General Paz'”, Guía de Córdoba Cultural no 15, (1982), p. 3.

10 Ana LongONI, "Incitar al debate, a una red de colaboraciones, a otro modo de hacer". Afuera. Estudios de Critica Cultural, $\mathrm{n}^{\circ} 13$ (2013). [en línea], http://www.revistaafuera.com/articulo.php?id=273\&nro=13 [Consulta: 15 de septiembre de 2014]. También se sugiere ver el Número especial, con motivo de cumplirse 40 años del Golpe de Estado de 1976: AAVV, $1976-2016$ Con-memoraciones, Afuera $\mathrm{n}^{\circ} 16$ (2016) [en línea], http://revistaafuera16.blogspot.com.ar/p/indice.html [Consulta: 16 de septiembre de 2016].

11 Municipalidad de Córdoba, "Proyección cultural desde el Museo Municipal de Bellas Artes y los Centros culturales periféricos" Guía de Córdoba Cultural, no 11, (1981), p. 44.

12 Raymond Williams, Sociología de la cultura, Buenos Aires, Paidós, 1994 [1981].

13 Pierre Bourdieu, Creencia artística y bienes simbólicos, Córdoba-Buenos Aires, aurelia*rivera, 2003.

14 Entre una treintena de entrevistas, cabe citar la Mesa de diálogo de 2015 mantenida con algunos ex integrantes de ADEV, a saber: Cáceres, Gallegos, Pérez y Torres. La misma fue coordinada por quien suscribe en la Escuela Superior de Bellas Artes "Doctor Figueroa Alcorta". Agradezco el apoyo brindado por la Prof. Sara Picconi en la organización de dicha actividad. 
cios oficiales admitieron micro-estrategias que tensionaban la "lógica de pasividad, compartimentación y desconfianza instalada por el régimen" 15 , en Córdoba permitieron resquicios para diálogos estético-políticos, libre expresión, acceso a lecturas internacionales, preservación de un estado de ánimo optimista y conformación de redes de compañerismo y amistad ${ }^{16}$.

Sobre la posibilidad de "agruparse", cabe recordar que el asociacionismo era reprimido a nivel nacional, desde los prolegómenos de 1976, en instituciones como las universidades y los partidos políticos ${ }^{17}$. Pero las entidades relacionadas con los mundos del arte, la cultura, el deporte y la religión detentaron en Córdoba tolerancias, permisos y fomentos. Los distintos campos artísticos fueron objeto de variaciones dentro de una política cultural que combinaba censuras con inauguraciones. Para 1982, un decreto del Poder Ejecutivo provincial advertía: "se prohibirá toda reunión que signifique una amenaza para la seguridad pública y se requerirá el previo aviso a la Autoridad Policial de toda Reunión convocada para lugares cerrados". Esa misma norma establecía la siguiente excepción:

Quedarán exentas de ello [...] Las reuniones que se producen en museos, galerías de arte, cinematógrafos, teatros, instituciones culturales y educativas, iglesias u otros lugares de culto, clubes y estadios deportivos, cuando el objeto real de la reunión resulte adecuado al lugar en el cual se realiza ${ }^{18}$.

Resta mucho por explorar respecto a los Centros Culturales de la última dictadura argentina. Investigaciones precedentes sobre Córdoba permitieron detectar tanto distancias como desplazamientos entre las políticas que los regulaban y los usos que diversos agentes fueron haciendo de ellos. Paralelamente, las relaciones que los artistas desplegaron con las instituciones estatales (tradicionales y nuevas) estuvieron condicionadas por las características históricas del campo artístico. Si bien la existencia de todo microcosmos está articulada por oscilantes reconstrucciones, es pertinente subrayar que, el campo plástico de Buenos Aires presentaba una antigua consolidación que vivenció permanencias, rupturas y retornos entre las décadas de 1960 y $1980^{19}$. En cambio, en esas mismas décadas, el microcosmos de Córdoba evidenciaba tenues cristalizaciones y una tradición de "patronazgo público" 20 . Atendiendo a las particularidades de esta trama local ${ }^{21}$ y nacional podemos complejizar los sentidos que condicionaron tanto

15 Daniela LuCENA, "La Zona-Loxon-Einstein: pintura en vivo y cooperación artística durante la dictadura militar argentina", El genio maligno, ${ }^{\circ} 14$ (2014), pp. 44-45. [en línea], http://elgeniomaligno.eu/ [Consulta: 16 de junio de 2015].

16 Los espacios de Córdoba definidos como "refugios" en las entrevistas fueron: las academias de artes visuales, las bibliotecas de la Facultad de Arquitectura de la UNC y del Instituto Goethe, casas de familia, cines clubes, el Teatro Luz y Fuerza, ciertos bares y los nuevos Centros Culturales barriales.

17 Como explica Bruno, el proceso represivo empezó en 1975 con la Misión Ivanissevich. Consistió en un conjunto de medidas que implicaron la intervención de la Universidad y un dispositivo de depuración. Se produjeron: el cierre tanto de los Departamentos de Cine y de Teatro como del Centro de Música Experimental, renuncias y despidos de la planta docente, expulsiones de estudiantes y "desaparición” de personas. Sol BRUNO, "Sobre ritmos y colores, ensayos y una obra: la Facultad de Artes", en M. Gordillo y L. Valdemarca (coords.), Facultades de la UNC. 1854-2011, Córdoba: UNC, 2013, pp. 346.

18 "Se prohibirá toda reunión que signifique una amenaza para la seguridad pública", La Voz del Interior, 28 de septiembre de 1982 , p. 7.

19 Entre los numerosos estudios emprendidos desde y sobre Buenos Aires, sugiero comenzar la consulta en tres trabajos: Andrea GIUNTA, Vanguardia, internacionalismo y politica. Arte argentino en los años sesenta, Buenos Aires, Siglo XXI, 2008. Ana Longoni, Vanguardia y revolución. Arte e izquierdas en la Argentina de los sesenta-setenta, Buenos Aires, Ariel, 2014. Viviana UsubiagA, Imágenes inestables. Artes visuales, dictadura y democracia en Buenos Aires, Buenos Aires, Edhasa, 2012.

20 Raymond Williams, 1994 [1981], pp. 36-40.

21 Entre los escasos estudios que contribuyen a la reconstrucción del período 1960-1980 en las artes visuales de Córdoba, puede consultarse: Gustavo BLÁZQUEZ, "El arte de contar la historia. Una lectura de la producción historiográfica sobre arte contemporáneo en Córdoba", en IV Congreso Internacional de Teoría e Historia de las Artes. Buenos Aires, CAIA, 2007, pp. 315329. Gabriel Gutnisky, Impecable-Implacable. Marcas de la contemporaneidad en el arte, Córdoba, Brujas, 2006. Dolores Moyano, La producción plástica emergente en Córdoba (1970-2000), Córdoba, Del Boulevard, 2005. Marcelo NusENOviCH, "Epidemias artísticas en Córdoba: la Viruela Boba (1966)", en IX Jornadas Interescuelas-Departamentos de Historia, Córdoba: UNC, 2003. María C. ROCCA, Arte, Modernización y Guerra Fría. Las Bienales de Córdoba en los '60, Córdoba: UNC, 2009. 
el pedido de un lugar de trabajo efectuado por ADEV a la Municipalidad, como la concesión que les hizo la comuna al prestarles el "subsuelo" del CCAC.

\section{De la conformación del grupo}

La actividad plástica 1982 analizada por tres jóvenes valores: Anahí Cáceres, Hernán Avendaño y Anahí Rodríguez. Forman parte de la Agrupación para el Desarrollo de Experiencias Visuales y en esta entrevista con Tiempo de Córdoba, exponen sus inquietudes ${ }^{22}$.

El párrafo anterior reproduce fragmentos de una primera noticia que publicaba datos sobre ADEV. En la sección Cultura y Espectáculos, un diario local transcribía una entrevista donde "tres jóvenes" creadores eran interrogados por un periodista sobre el cual sólo se aportaba sus iniciales, a saber: M.U. Transcurridas más de tres décadas, los recuerdos de Cáceres permiten conocer que aquellas iniciales hacían referencia a una agente del campo cultural de los años 80: "la viuda de Krivoruk, Marta Uriarte. En esa época escribía críticas de arte en ese diario"23. Analizando esa fuente periodística podemos ir desanudando algunos hilos para caracterizar al contexto y al grupo. Enero de 1983 devenía un momento propicio para hacer un balance sobre el año precedente. Al respecto, la entrevista de Tiempo de Córdoba sintetizaba:

-MU: ¿Cómo visualizaron el panorama de 1982?

-HA: creo que no hubo variaciones respecto a años anteriores, salvo la intención de un grupo de gente que expusieron en Arte Joven 82 [...]. Otra cosa importante fueron las muestras que se trajeron desde Alemania, de Düsseldorf y de Sttutgart.

-AR: A pesar que esas propuestas fueron realizadas hace una década [...]

-AC: en Córdoba resurgió una fuerza que estaba callada, de gente joven y no tan joven, con deseos de realizar y mostrar cosas distintas, no es casualidad que hayan surgido otros grupos: Arte Nuevas Respuestas, Siete Individuales, gente que está en una búsqueda libre, que no está totalmente en la vanguardia, pero si en una actitud más independiente como se realizó hace un tiempo en Córdoba con las bienales y los salones juveniles ${ }^{24}$.

En ese diálogo, Avendaño destacaba positivamente dos cambios en las exposiciones de 1982: uno local, la muestra Arte Joven organizada desde el Museo Provincial de Bellas Artes Emilio Caraffa (MPBA); otro internacional, la exhibición de obras alemanas concretada en el Centro Cultural General Paz (CCGP) ${ }^{25}$. Respecto de estas últimas, Rodríguez subrayaba que no se trataba de un suceso contemporáneo a sus años 80, sino de propuestas emergentes en la década del 70. Cáceres, por su parte, conectaba las vivencias de su presente con dos series de acontecimientos desarrollados en las artes provinciales desde la década de 1960: en principio, las tres ediciones de una bienal artística que conmocionó a Córdoba con circulaciones

${ }^{22}$ M.U. [Marta Uriarte], entrevista con Anahí Cáceres, Anahí Rodríguez y Hernán Avendaño, “Plástica. La necesidad de nuevas propuestas", Tiempo de Córdoba, 24 de enero de 1983, p. 11.

${ }_{23}$ Entrevista realizada por la autora con Anahí Cáceres, en Buenos Aires, el día 3 de noviembre de 2016. No encontramos mayores datos sobre Marta Uriarte. En cambio, el pintor Benjamín Krivoruk (1931-1973), es registrado en: Dolores MoYANO, Diccionario de Artistas Plásticos de Córdoba, Córdoba, Imprenta de la Lotería, 2010, p. 284.

${ }^{24}$ M.U. [Marta Uriarte], entrevista con Anahí Cáceres, Anahí Rodríguez y Hernán Avendaño, "Plástica. La necesidad de nuevas propuestas", Tiempo de Córdoba, 24 de enero de 1983, p. 11.

${ }_{25}$ La muestra Arte Joven fue parte de otras políticas culturales que en la Argentina dictatorial y posdictatorial (particularmente en Córdoba) estuvieron dedicadas a "los jóvenes". Alcanzó cuatro ediciones consecutivas abiertas a dibujo, escultura, grabado, pintura y experiencias. La exposición alemana remarcada por Avendaño había sido anunciada anteriormente en la prensa: "La poesía a través de la materia, la luz y el movimiento, un aporte del Instituto de Relaciones Culturales con el Exterior Stuttgart". Allí se exhibieron obras de "26 autores de la República Federal de Alemania". "Hoy será inaugurado el Centro Cultural General Paz”, La Voz del Interior, 2 de julio de 1982, p. 7. 
de obras y agentes nacionales, panamericanos y europeos ${ }^{26}$; seguidamente, los salones juveniles organizados por el MPBA. Para ella, en 1982 había resurgido "una fuerza que estaba callada", una potencia que comparaba con las posibilidades de aquellos efervescentes años 60 , cuyos proyectos fueron (en parte) interrumpidos con el Golpe de Estado de 1966 encabezado por el comandante Onganía ${ }^{27}$.

Entre los re-nacimientos artísticos de 1982, Cáceres señalaba a otros dos grupos mayoritariamente "juveniles"; a quienes, como al propio ADEV, no consideraba "totalmente en la vanguardia", pero sí en búsquedas "libres", novedosas y diferenciales. Al respecto, cabe especificar dos factores contextuales. Por un lado, en el microcosmos de la plástica, la rotulación "artista joven" podía asignar tres capitales: el término "artista" refería tanto a un capital cultural como a un recurso simbólico ${ }^{28}$; paralelamente, la palabra "joven" funcionaba como otro capital simbólico que remitía a las características esencializadas de una etapa vital determinada ${ }^{29}$. Por otro lado, en el macrocosmos nacional, 1982 fue un año crucial para Argentina, entre otras razones, porque la derrota ante Inglaterra en la Guerra de Malvinas precipitó la crisis de la dictadura cívico-militar, una coyuntura donde se multiplicaron presencias y ausencias juveniles.

Con el diario Tiempo de Córdoba también podemos introducirnos en las complejidades de la política cultural dictatorial. Si bien los entrevistados por el periódico coincidían en señalar que recién en 1982 habían accedido a un clima social que les permitía "experimentar libremente"; también reconocían que las novedosas propuestas de aquella coyuntura habían "sido apoyadas por la provincia y la municipalidad como no se lo hacía desde hace mucho tiempo". Avendaño explicitaba la necesidad de "organizar un apoyo oficial y privado", una tarea prioritaria ante la crisis económica del país que, en el terreno artístico implicó el descenso de ventas en galerías, entre otras dificultades ${ }^{30}$.

Sobre los patrocinios obtenidos, la noticia destacaba el préstamo de un lugar para el trabajo del grupo, un subsuelo cedido por el Municipio en el Centro Cultural Alta Córdoba. Ese espacio fue resignificado por ADEV, cuyos integrantes transformaron el sótano en un taller. En marzo, otro periódico aportaba detalles sobre dicho sitio:

[...] el subsuelo del ex mercado de Alta Córdoba, convertido desde hace algún tiempo en uno de los modernos y agradables centros culturales con que cuenta la ciudad. Allí en medio de tuberías y conductos, de aire acondicionado, en ambiente surrealista, hay esparcidas pinturas, tapices, telas, una filmadora, lanas, un muñeco de madera (a medio hacer)

Es este un equipo [...] que hace tiempo solicitó a la comuna, un lugar donde desarrollar las tareas. Gesto que no olvidan agradecer, mientras recuerdan que fue el Director de Promoción Cultural, Manuel Solís quien se interesó en la idea ${ }^{31}$.

\footnotetext{
26 Sobre las Bienales Americanas de Arte auspiciadas por Industrias Kaiser Argentina (IKA) entre 1962 y 1966, ver RocCA, 2009.

27 Para Córdoba quedan muchas lagunas por explorar respecto a las (dis)continuidades en los procesos artísticos sucedidos entre el Onganiato (1966-1973), el tercer gobierno peronista (1973-1976) y la última dictadura (1976-1983). Por ejemplo, el archivo del Museo Caraffa registra el desarrollo de cinco ediciones de un Salón Juvenil de Artes Plásticas entre 1966 y 1970 ; mientras en 1982 reverberó otro ciclo de muestras “juveniles” en dicha institución. Listado de muestras 1930-2003. Archivo del MPBA, Córdoba, s/f.

28 Cf. Bourdieu, 2003.

29 Sobre los dos grupos mencionados por Cáceres, otras fuentes nos permiten conocer que Arte Nuevas Respuestas fue un ciclo organizado por la Sociedad de Arquitectos de Córdoba desde agosto hasta octubre de 1982; allí expusieron: Giorgis-Matelo, Longhini-Falco, Carranza y Castiglia, Capardi, Reyeros y Caturelli (“Arte: nuevas respuestas”, La Voz del Interior, 1 de agosto de 1982, p.7). En octubre de 1982 otra noticia otorgaba visibilidad a una muestra colectiva concretada en el CCGP, llamada Siete Individuales. Compartía con el grupo precedente una dupla de productores, mientras el nombre hacía referencia a la cantidad de integrantes: Baena, Capardi, Castiglia, Echevarrieta, Romano, Simes y Torres ("Siete Individuales", La Voz del Interior, 22 de octubre de 1982, p.9). Torres se sumará seguidamente a ADEV. Entre las características compartidas por estos tres colectivos artísticos la prensa epocal destacaba: "juventud, heterogeneidad, experimentación, novedad".

30 M.U. [Marta Uriarte], entrevista con Anahí Cáceres, Anahí Rodríguez y Hernán Avendaño, “Plástica. La necesidad de nuevas propuestas", Tiempo de Córdoba, 24 de enero de 1983, p. 11.

31 "Cuando investigar es un arte", La Voz del Interior, 6 de marzo de 1983, p. 6.
} 
Ese espacio, concedido por un funcionario gubernativo y $\operatorname{artista}^{32}$, fue un factor delimitante tanto para la conformación y el crecimiento del "grupo de artistas y artesanos" como para sus proyectos de "investigación"33. En esa misma fuente, mientras se anunciaba su primera muestra, se explicitaba:

En la actualidad somos nueve [...] este no es un grupo cerrado, la intención es aglutinar a más gente, hasta llegar a ser $15 \ldots$ más no por el problema del espacio.

[...] La exposición que haremos en abril estará integrada por cuarenta obras: composiciones tridimensionales de gran tamaño, estructuras móviles, obras bidimensionales y con efectos lumínicos. ${ }^{34}$

\section{Generalidades de la muestra fundacional}

Con un mes de demora comenzó la "exposición presentación” de ADEV, la cual estuvo abierta al público durante dos semanas, entre mayo y junio de 1983. Además de convocatorias personalizadas efectuadas por los expositores a sus círculos afectivos y artísticos, se invitó a la comunidad en general. Un periódico convocaba al acto inaugural que comenzaría "a las 19 horas con una conferencia sobre Arte y Tecnología" 35 . Cotejando ese diario con el afiche de la muestra detectamos tres redes de posiciones, relaciones y distinciones entre los productores (fig. 1).

Distintas fuentes nombraban alfabéticamente a nueve expositores integrantes de ADEV, quienes exhibían sus obras en el mismo subsuelo donde funcionaba el taller: Hernán Avendaño, Anahí Cáceres, Selva Gallegos, Pablo González Padilla, Malena La Serna, Oscar Páez, Susana Pérez, Patty Stöck y Jorge Torres. También se detallaban otras tres tareas y los agentes que las desempeñaban: la iluminación era realizada por Julio Benavidez, la música pertenecía a Alejandro Baró y la conferencia estaba a cargo de Gregorio Dujovny. Un tercer documento, el folleto-cubo, indicaba que Dujovny era, además, uno de los dos "artistas invitados" (el otro era Jorge Schneider), a quienes se habían asignado salas expositivas en la planta alta del CCAC (fig. 2).

Tanto el periódico y el afiche como el folleto-cubo reproducían en mayo la foto de nueve expositores integrantes ${ }^{36}$. Ello implicaba que el número de miembros se había triplicado en cuatro meses, pues (como explicamos en la sección anterior), el diario de enero había nombrado a "tres jóvenes". De aquel trío inicial, solo persistían dos agentes, ya que Rodríguez se había retirado. Respecto a esa compañera, Cáceres explica: "Se apartó del grupo por falta de tiempo antes de la muestra en Alta Córdoba [...] Hacía artesanías en cueros, dibujos y pinturas" ${ }^{37}$. A la vez, los recuerdos de Rodríguez permiten percibir que, como sucedió con varias mujeres en aquellos años, las dificultades familiares afectaron a sus planes laborales:

R: Cuando bajamos [al sótano] era un basural.

G: de cosas de construcción.

R: empezamos a limpiar, a trabajar [...] Yo hice mi proyecto, estábamos todos muy entusiasmados, pero yo tenía muchos problemas en ese momento así que abandoné el grupo. Tenía mi niño pequeñito y estaba recién separada. Me retiré, pero nunca he dejado de estar conectada con mis amigos, mis colegas ${ }^{38}$

\footnotetext{
32 Solís se desempeñó como Director de Promoción Cultural entre 1981 y 1983; las fuentes lo nombran indistintamente como arquitecto o escultor.

33 "Cuando investigar es un arte", La Voz del Interior, 6 de marzo de 1983, p. 6.

34 Ibidem.

35 "Presentación del grupo ADEV", La Voz del Interior, 26 de mayo de 1983, p. 9.

${ }^{36}$ Mientras el folleto-cubo enumeraba un listado de ocho expositores y cinco colaboradores-invitados (situando a Pérez en este último ámbito), el afiche diferenciaba tres colaboradores-invitados y nueve expositores (incluyendo aquí a Pérez). Fue esta última versión la que predominó en los diarios.

37 Entrevista realizada por la autora con Anahí Cáceres, en Buenos Aires el día 3 de noviembre de 2016.

38 Entrevista realizada por la autora con Selva Gallegos y Anahí Rodríguez, en Córdoba, el día 6 de noviembre de 2016.
} 


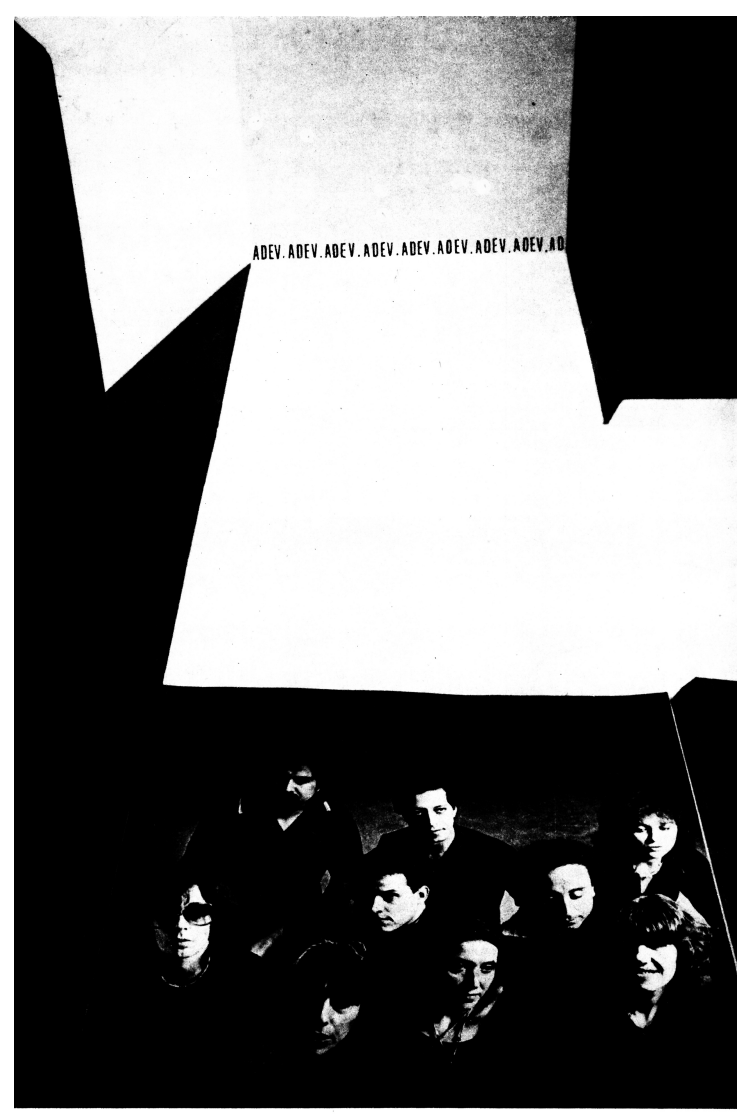

27 de mayo a 10 de junio 1983 Exponen : H.AVENDAÑo, A.CACERES, S.GALLEGOS, gonzalez padilla, M. la Serna, o.PAEZ, S. PEREz, P.STÖCK, J.TORRES

lluminacion: J.Benavidez Conferencia : G.DUJOvNY

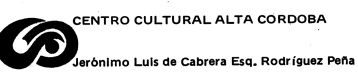

$$
\text { Muisica : A. Baró }
$$

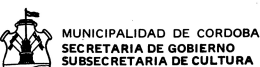
MUNICIPALIDAD DE CORDOBA
SECRETARA DE GOBERNO
SUBSECRETARIA DE CULTURA

Fig. 1. ADEV, Afiche de la Exposición en el Centro Cultural Alta Córdoba. 1983, Córdoba. (Imagen recuperada del Archivo digital de Anahí Cáceres).
Para la exhibición se confeccionó un segundo folleto que se plegaba en once sectores, cada uno de los cuales contenía diversos textos. El primero ofrecía un párrafo firmado colectivamente por $\mathrm{ADEV}$, los nueve espacios siguientes aportaban frases poéticas suscritas individualmente por cada integrante, el último fragmento reproducía nombres y símbolos de las entidades auspiciantes (escudo del Municipio y logotipo del CCAC). El primer párrafo posibilita leer (auto)definiciones compartidas en torno a las cuatro palabras cuyas iniciales constituían el nombre del equipo. Allí, las frases ubicadas al inicio y al final daban cuenta de avances y limitaciones en la conformación de la "agrupación", mientras las oraciones del medio explicitaban objetivos y creencias compartidos. En palabras de ADEV:

Más allá de las búsquedas individuales de estilo y lenguaje, y del respeto por el acto íntimo de la creación artística, surge una realidad ineludible: la del trabajo conjunto para el aprendizaje y la investigación.

El interés común por el desarrollo de técnicas y la necesidad de transmitir a través de la obra una realidad acorde a nuestras vivencias, nos impulsó a formar en Córdoba, desde fines de 1982, una agrupación para investigar materiales, instrumentos, procedimientos, técnicas, conceptos estructurales, etc., diferente a los utilizados tradicionalmente.

Creemos que la experimentación de nuevas técnicas y el intercambio de conocimientos, contribuirá a la realización de una labor creativa profunda, que permita una comunicación fluida con el espectador.

Si bien la serie de trabajos que hoy exponemos no constituye aún el resultado de experiencias grupales, son sí el producto de un esfuerzo común y el punto de partida individual de esta tendencia a la actividad creadora libre ${ }^{39}$.

ADEV anunciaba desde su nominación un propósito, a saber: "el desarrollo de experiencias visuales". Esas palabras les permitían rotular diversas concepciones de los años 80 sobre el arte. En los documentos del grupo encontramos tanto una valoración del intercambio entre trabajo individual y aprendizaje colectivo como un acento en el proceso creativo "libre y diferente", donde técnicas, materiales y conceptos "nuevos" desafiaban "tradiciones" mediante "investigación y experimentación". Por su parte, en la obra final recaía una función social central: devenir canal para "trasmitir realidades" de los artistas (sus vivencias contemporáneas) hacia un espectador con quien se pretendía establecer una "comunicación fluida". Desde esa clave, podemos interpretar al folleto-cubo distribuido gratuitamente al público, cuyo diseño podía devenir un recuerdo resguardado como objeto bi o tridimensional.

39 ADEV, Folleto de la exposición-presentación desarrollada, en el Centro Cultural Alta Córdoba, en mayo de 1983, pp. 1-2. 


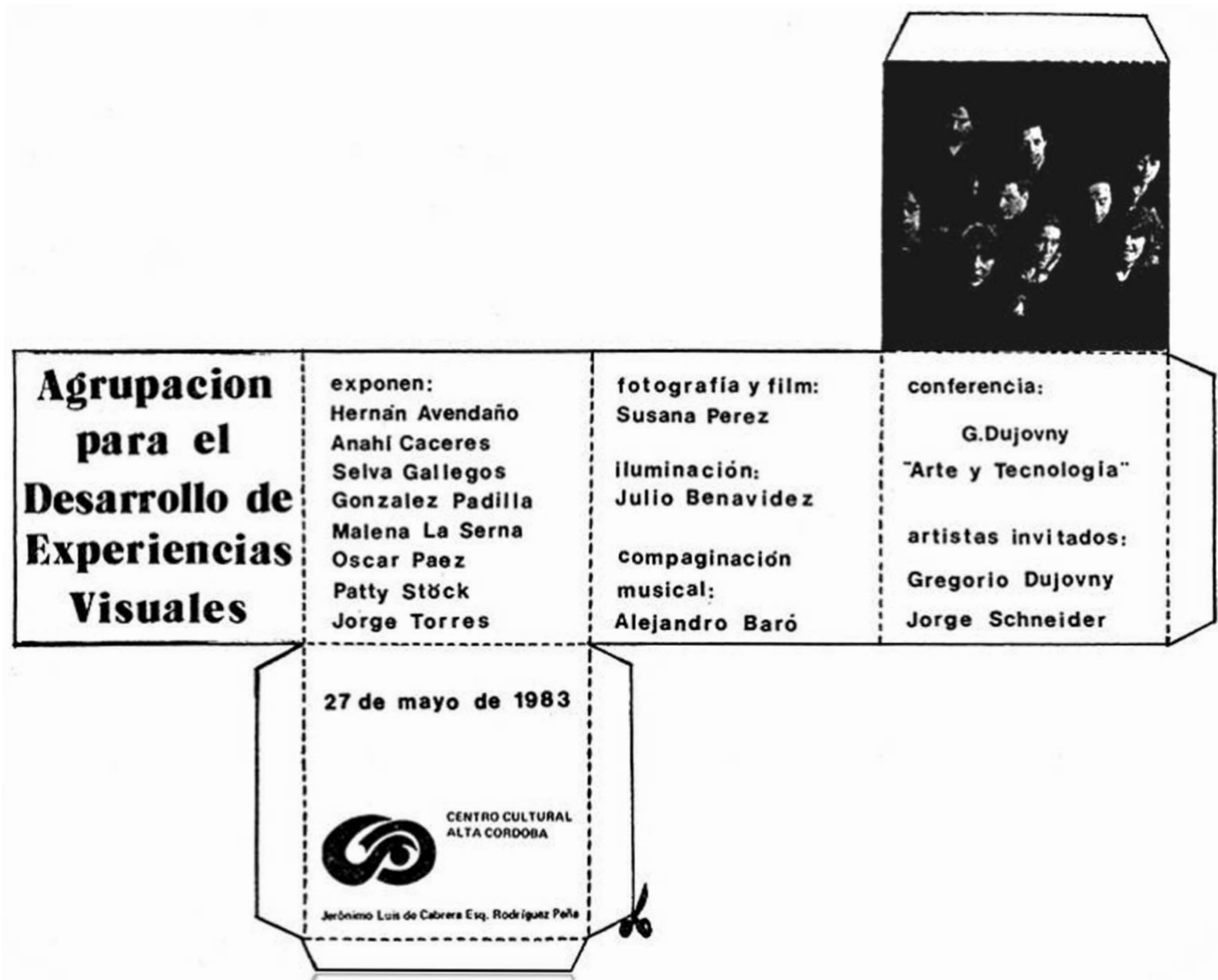

Fig. 2. ADEV, Folleto-cubo de la Exposición en el Centro Cultural Alta Córdoba. 1983, Córdoba. (Imagen recuperada del Archivo digital de Anahí Cáceres).

Como alerta epistemológico, cabe señalar que la díada "experiencias visuales" abre una serie de cuestiones sobre posibles reverberaciones de prácticas sesentistas y setentistas cuya exploración excede los objetivos de este artículo: por una parte, las bienales, el I Festival Argentino de Formas Contemporáneas ${ }^{40}$, los salones y las muestras juveniles desplegadas en Córdoba; por otra, las propuestas, exposiciones y premios desarrollados en Capital Federal desde el Instituto Di Tella, los circuitos alternativos, el Salón Nacional y el Centro de Arte y Comunicación ${ }^{41}$. Paralelamente, se abre un tercer eje de preguntas sobre potenciales contactos de ADEV con otras agrupaciones que estaban surgiendo a principios de los años 80 en ciudades como Buenos Aires y Rosario ${ }^{42}$.

\section{Tras las huellas de las "experiencias" artísticas}

"Inquietar la mirada" en torno a las obras, definidas por ADEV como experiencias visuales y expuestas en el CCAC, resulta la tarea más compleja de esta historia, entre otras razones, porque no se

40 Sobre esos dos eventos cordobeses, ver: Guillermo FANTONI, "Tensiones hacia la política. Del homenaje al Viet-Nam a la Anti Bienal”, Revista Sisi, Año 2, nº 2 (1990), Rosario. Nusenovich, 2003; RoccA, 2009.

41 Entre los estudios emprendidos desde Buenos Aires, puede consultarse: GiUnTA, 2008. LongOnI, 2014.

42 Red Conceptualismos del Sur, Perder la forma humana. Una imagen sísmica de los años ochenta en América Latina. Madrid: MNCARS, 2012. 
realizó un catálogo con reproducciones de las mismas ${ }^{43}$. Además, los productos artísticos de los años 80 presentan inabarcables diseminaciones en el siglo XXI. Un fragmento minoritario (los premiosadquisición) ha sido resguardado en los museos; pero la mayoría de obras exhibidas en muestras se encuentran disgregadas en recintos privados. Así, los archivos personales de los artistas resultan centrales al momento de reponer algunas piezas del panorama de las artes que se producían y circulaban durante aquella década ${ }^{44}$.

Sobre los productos exhibidos por ADEV en 1983, podemos aproximarnos a escasas imágenes a partir del cotejo de diarios, folletos, testimonios y fotos. Allí, detectamos tres sub-grupos. Por un lado, diversas fuentes coinciden en explicitar que cinco de los nueve integrantes presentaron obras pictóricas; las cuales, distanciándose del gusto dominante por figuras humanas idealizadas y paisajes neoimpresionistas, tensionaron los límites de "la pintura tradicional". Por otro lado, el análisis de los documentos permite interpretar que los cuatro integrantes restantes participaron con propuestas que traspasaban las fronteras disciplinares de artesanía, cine, escultura, fotografía, instalación, objeto y pintura. Un tercer subgrupo correspondió a las obras de dos artistas invitados que, según la prensa, combinaban "trabajos cinéticos y audiovisuales" 45 . Atendiendo a las restricciones cuantitativas de todo artículo y a las fuentes cualitativas relevadas, en este texto profundizaremos solamente en el análisis del primer y segundo subgrupo.

Conseguimos un acercamiento (indirecto) a las experiencias visuales, si agudizamos la lectura del folleto que acompañó a la muestra, donde los miembros plasmaron nueve textos literarios. Esos escritos tenían formatos diversos: fueron redactados en primera o tercera persona, como poesía o prosa, con autoría propia o cita. Cabe subrayar que sus contenidos (a diferencia de otros catálogos epocales donde se reproducían los currículos de los artistas) no ofrecían al lector datos biográficos sino una especie de mini manifiestos. Allí podemos ensayar una lectura, en clave sociológica, de "estructuras de sentimientos" respecto a distintos tópicos: arte, artista, contexto, público ${ }^{46}$.

Comenzando por el subgrupo pictórico, en el sector del folleto firmado por Jorge Torres, encontramos una cita de fragmentos del pintor y poeta belga del Grupo Cobra Pierre Alechinsky (1927-). Un año antes, en 1982, Torres definía: "La pintura es, a veces, gesto y ritmo; acto que recrea, como la fiesta o el rito, el hecho de estar vivos" ${ }^{4}$. Comparándolo con ese texto, el escrito de 1983 mostraba un contenido más encriptado:

43 En este apartado se retoman, entre otros autores, los aportes de la teórica chilena Richard cuando sostiene que: "Ciertas formas de trabajar con los signos (las del arte) saben producir vibraciones intensivas en contra de los lenguajes uniformes del diseño, de la publicidad y de los medios, haciendo que sus formas introduzcan la ambivalencia en los juegos seriados de la equivalencia homogénea, para inquietar -en lugar de aquietar- la mirada". Nelly RicHARD, Fracturas de la memoria, Buenos Aires: Siglo XXI, 2007, p. 106.

44 Para la reconstrucción de ADEV han sido centrales las entrevistas con Cáceres y Gallegos (2015, 2016), pues permitieron acceder a sus archivos personales y grupales.

45 "Presentación del grupo ADEV", La Voz del Interior, 26 de mayo de 1983, p. 9.

46 Raymond Williams, Marxismo y literatura, Barcelona, Península, 2000 (1977). Combinando los conceptos de Williams con otros aportes, se sostiene la siguiente hipótesis: dentro de esa urdimbre sistematizada que fue el régimen dictatorial en Argentina, donde se congregaron militares y civiles en acuerdos explícitos y consensos silenciosos, también emergieron "intersticios de resistencia" (Michel Foucault, Microfísica del Poder, Madrid, La Piqueta, 1992). En el ámbito de las artes plásticas de Buenos Aires y Córdoba, observamos que desde lenguajes tradicionales como la pintura hasta géneros emergentes como la instalación, algunos creadores construyeron obras que con sus temáticas, estilos, títulos, materiales y/o montajes curatoriales, proponían existencias disruptivas respecto a los cánones estético-éticos que cimentaban al gusto oficial. Paralelamente, (re)construían "estructuras de sentimientos" que daban cuenta de sus vivencias contemporáneas: incertidumbre, violencia, confusión, silencio, ausencia, muerte, personajes y ambientes desfigurados, descentrados e inestables. Cf. Mariana MARCHESI, "Discursos de resistencia", en XXIV International Congress of the Latin American Studies Association (Dallas, Texas, March 27-29, 2003), pp.1-18. [en línea] http://lasa.international.pitt.edu/Lasa2003/MarchesiMariana.pdf [Consulta: 16 de septiembre de 2017]. UsuBIAGA, 2012, p. 18-ss.

47 Pablo Baena, Daniel Capardi, Ricardo Castiglia, Alfredo Echevarrieta, Tulio Romano, Jorge Simes y Jorge Torres, "Siete Individuales", (catálogo de exposición realizada en octubre de 1982 en el Centro Cultural General Paz, Córdoba), p. 6. 


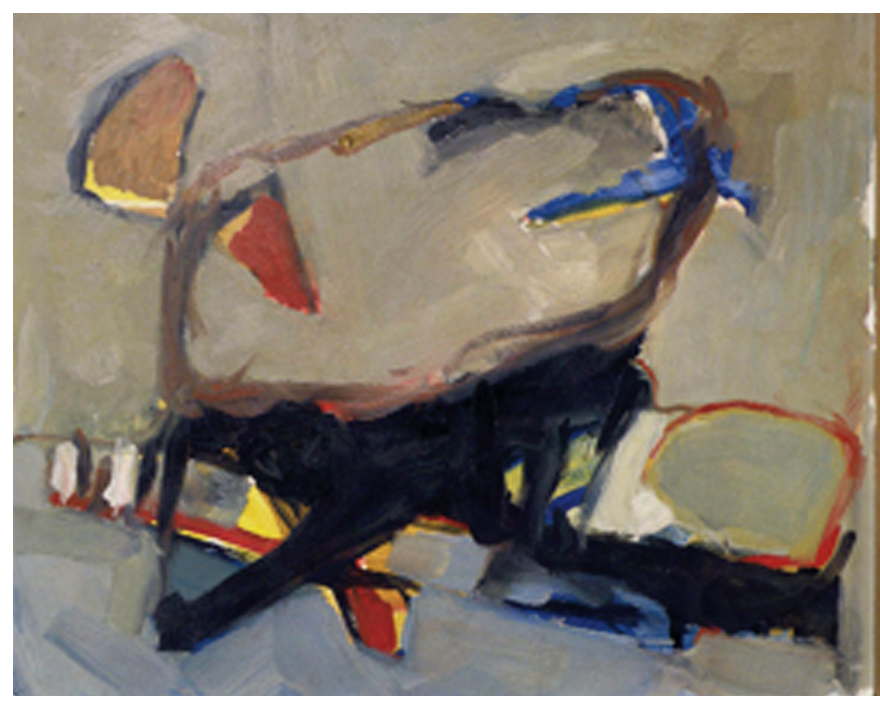

Fig. 3. Torres, Jorge, sin título, 1982, óleo sobre madera, $50 \mathrm{x}$ $60 \mathrm{~cm}$. Córdoba. Colección del Museo Provincial de Bellas Artes "E. Caraffa". (Imagen recuperada del Catálogo de la Muestra Caprichos. Ciudad de las Artes. Gobierno de Córdoba. 2013, p.102).

Con los brazos separados, reúne las semejanzas, cree haber previsto todo, haberse adelantado. Son los pincelazos regulares los que lo acaban, Decorado: Lluvia imperfecta

12/ La retina sólo ha retenido las manchas

Decorado: Suelo próximo

13/ Inclinada sobre el que ve al revés sin relación

14/Inclinada sobre el que opta por su gran bocado

15/Inclinada sobre el que no puede más y que

16/Inclinada sobre el que $\mathrm{No}^{48}$

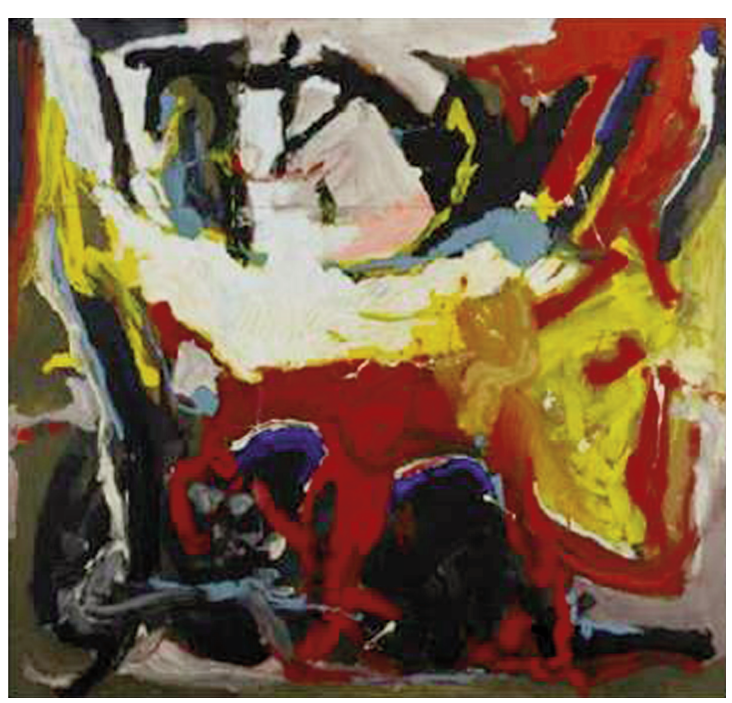

Fig. 4. Torres, Jorge, Danza de los brujos, 1983, pintura industrial sobre hardboard. 169,5 x 182,5 cm. Donación del artista, 2008, Córdoba, MPBA. [ $\mathrm{N}^{\circ}$ de inventario: 1283] [en línea], pestañas Colección/ Obras/T/Torres del sitio web http://www.museocaraffa.org.ar/ [Consulta: 16 de febrero de 2017]

Junto a esa cita que aludía a (in)visibilidades, pinceladas exacerbadas, desniveles y reveses, testimonios actuales y documentos antiguos permiten deducir que Torres había expuesto cuadros donde plasmaba re-apropiaciones del expresionismo abstracto (figs. 3 y 4). Por su parte, Selva Gallegos expuso una serie en 1983 donde también entrelazaba pintura y poesía, pero su producción visual y textual ponía el acento en un acontecimiento del año previo que había conmovido al macrocosmos del país: la guerra contra Inglaterra por las Islas Malvinas $^{49}$. Desde una posible lectura de sus cuadros, considero que la combinación predominante de tonalidades blancas y grises contribuía a desplazar la atención del espectador hacia dos escenas dramáticas que evocaban la derrota y el clima oceánico subpolar de aquellas islas: en un caso, un avión caído que portaba símbolos patrios argentinos, en otro, un cuerpo humano inmóvil y vendado que yacía en una camilla (figs. 5 y 6).

48 ADEV, “Jorge Torres". Folleto de la exposición-presentación desarrollada, en el Centro Cultural Alta Córdoba, en mayo de 1983 , p. 2.

49 En esa "guerra convencional" por las Islas Malvinas, librada en el primer semestre de 1982, Argentina movilizó, entre otros sujetos, a 12.000 jóvenes conscriptos; "el saldo" de la derrota fue de 649 cadáveres, 1300 heridos, numerosos prisioneros y posteriores suicidios. Al respecto, ver: Federico Lonenz, Las guerras por Malvinas, Buenos Aires, Edhasa, 2006. 


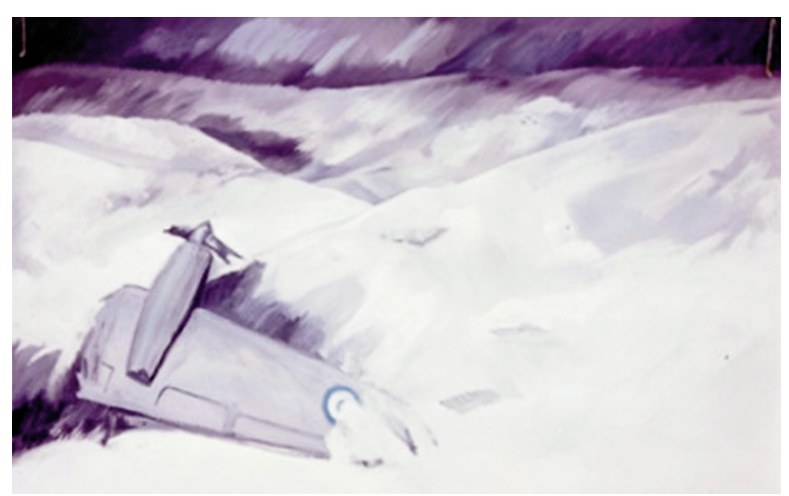

Fig. 5. Gallegos, Selva. De la serie Pinturas blancas sobre la Guerra de Malvinas, 1983, pintura industrial sobre madera. $120 \times 150 \mathrm{~cm}$ (circa), Córdoba. (Foto recuperada del Archivo personal de la artista).

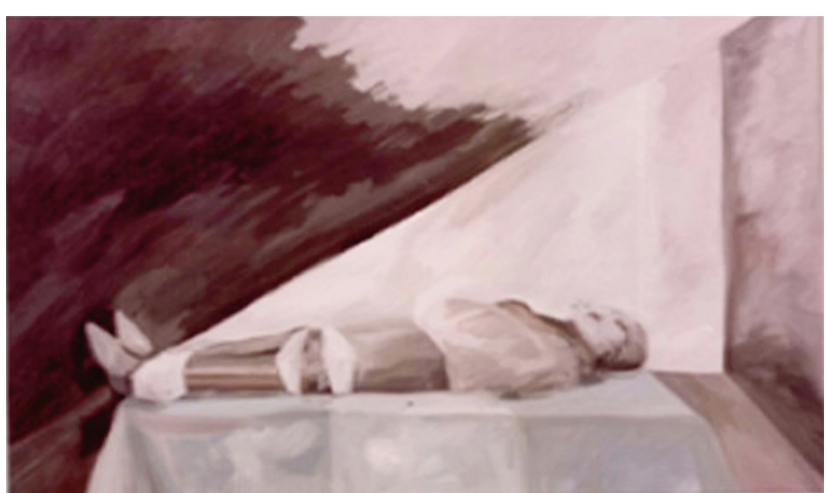

Fig. 6. Gallegos, Selva. De la serie Pinturas blancas sobre la Guerra de Malvinas, 1983, pintura industrial sobre madera. $120 \times 150 \mathrm{~cm}$ (circa), Córdoba. (Foto recuperada del Archivo personal de la artista).

Otro de los cuadros de Gallegos mixturaba dos paneles, el de la izquierda con Paisajes blancos, el de la derecha con citas de las Elegías de Duino, pertenecientes al poeta alemán Rainer María Rilke (18751926). Conjuntamente, una poesía, que tenía por autora a la propia Gallegos y era colocada en su sector del folleto, engrosaba el peso simbólico de aquellas imágenes conformando "vibraciones intensivas" que aludían a la violencia vivenciada en un espacio (no solo) insular ${ }^{50}$ :

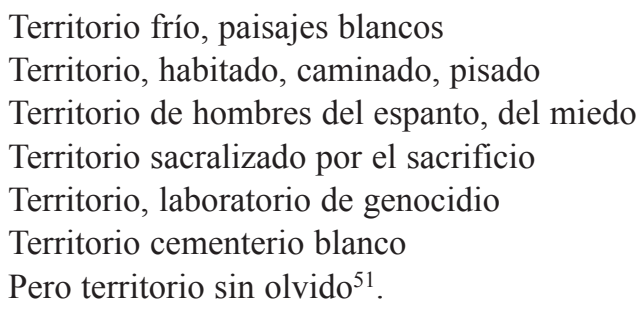

La recitación artística de la palabra "genocidio" adquiría una densidad particular en 1983, cuando los medios de comunicación aumentaron el volumen y la visibilidad de las denuncias, concretadas por organismos defensores de Derechos Humanos, sobre el "poder desaparecedor" extendido por diversas políticas desde el preludio del golpe estatal de $1976^{52}$. Una noticia posterior, sobre una muestra concretada por

50 Cf. RICHARD, 2007, p. 106.

51 ADEV, "Selva Gallegos". Folleto de la exposición-presentación desarrollada, en el Centro Cultural Alta Córdoba, en mayo de 1983 , p. 1.

52 Pilar CAlveiro, Poder y desaparición. Los campos de concentración en Argentina, Buenos Aires, Colihue, 1998. En Argentina "genocidio" fue aplicado secundariamente para nombrar responsabilidades y abusos de la Guerra de Malvinas; principalmente fue usado para designar al Terrorismo del Estado Dictatorial que implementó dispositivos represivos diversos: secuestros, detenciones en centros clandestinos, torturas, ejecuciones, ocultamiento de cadáveres, apropiación de niños. Por ejemplo, en 1983 la agrupación Madres de Plaza de Mayo visitaba la ciudad de Córdoba y refutaba en la prensa el argumento oficial de "guerra contra la subversión", denunciando que sus "jóvenes hijos" habían sido víctimas de "un genocidio" (LVI, 11 de junio de 1983). En 1984 la CONADEP "publicó una lista con casi 10.000 nombres de personas que habían sido denunciadas como detenidos-desaparecidos", actualmente los organismos defensores de DDHH reclaman por 30.000 personas. CONADEP, Nunca más. Informe de la Comisión Nacional sobre la desaparición de Personas, Buenos Aires, Eudeba, 2000 (1984). [en línea], http://www.desaparecidos.org/arg/conadep/lista-revisada/ [Consulta: 1 de marzo de 2017]. 


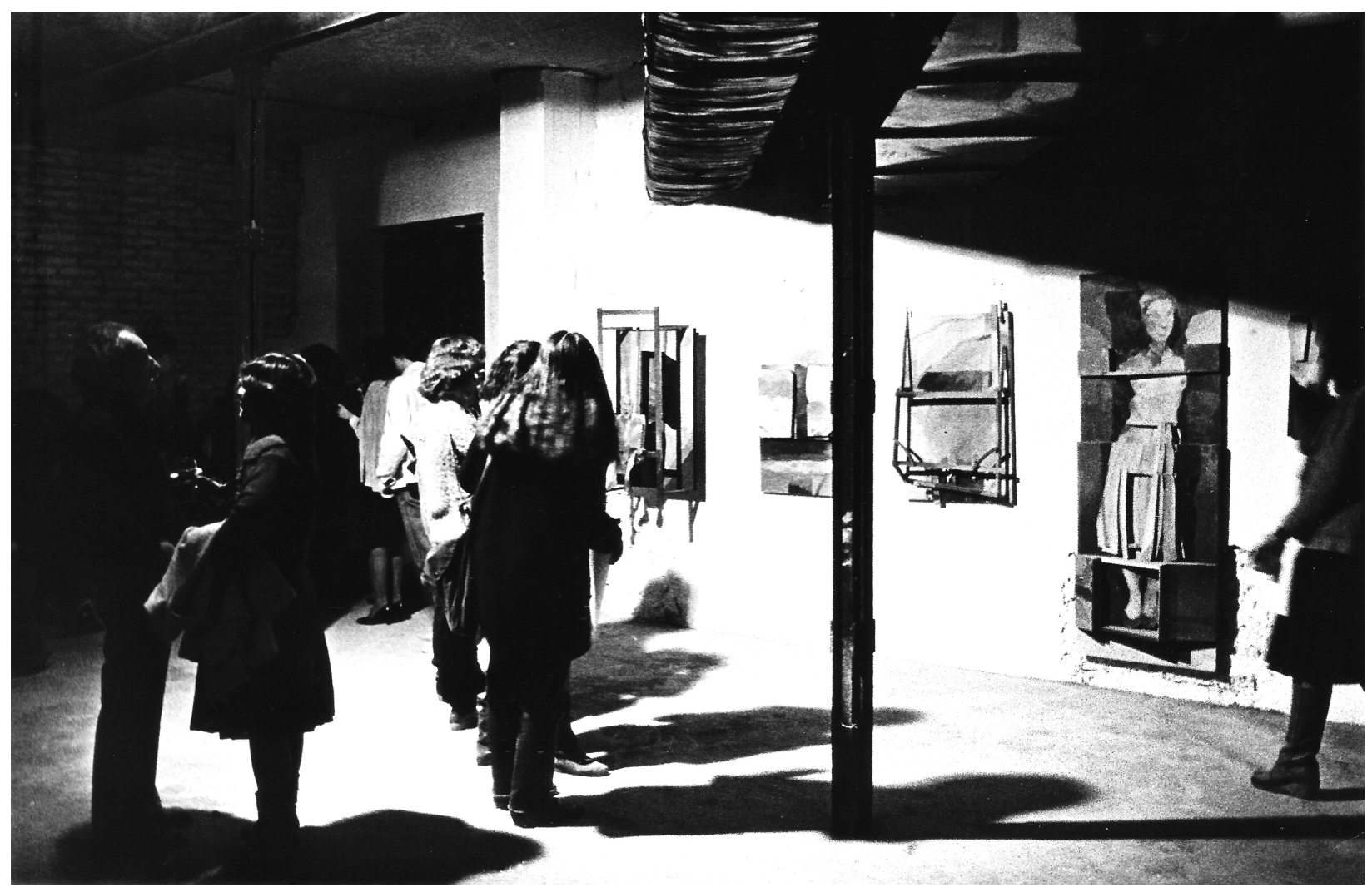

Fig. 7. Avendaño, Hernán, Pinturas, sin datos. Exposición de ADEV en el CCAC, 1983, Córdoba. (Fotografía tomada por Susana Pérez y recuperada del Archivo digital de Cáceres).

ADEV en la ciudad de Tucumán en el semestre siguiente, ofrecía un listado de los integrantes que producían y exponían "pinturas", el cual era encabezado por La Serna y González Padilla ${ }^{53}$. En un primer relevamiento no conseguimos imágenes de sus obras; sin embargo, en el folleto del CCAC accedemos a dos frases que aportarían pistas sobre algunos pensamientos y emociones. La Serna se (auto)definía transitando exploraciones, oscuridades y encrucijadas: "El aprendizaje es una búsqueda en todo, en lo más pequeño, en lo más recóndito, en lo bueno y en lo malo. En algún momento se enciende una luz y se sigue en una sola y determinada dirección" 54 . Padilla asignaba un predicado sobre un sujeto tácito donde plasmaba, en mayúsculas, una proclama de su trabajo artístico: "PINTO PARA NO VOLVERME LOCO"55.

En el caso de Hernán Avendaño, dentro del sector del folleto que integraba a la muestra de ADEV en el CCAC, encontramos otro escrito individual de autoría propia, donde se explicitaban múltiples "necesidades" que traspasaban el microcosmos pictórico para introducirse en el macrocosmos social de aquel presente:

Siento la necesidad de hacer una pintura coherente con mis vivencias cotidianas, de abandonar los prejuicios aprendidos, los materiales estáticos y las proporciones lógicas.

[...] de olvidar esa caprichosa denominación de artista para sentirme un constructor, amante de su oficio y de su gente.

53 “Artes plásticas. Presentación de unos cordobeses", La Gaceta, 2 de diciembre de 1983, Tucumán, p. 11.

54 ADEV, "Malena La Serna". Folleto de la exposición-presentación desarrollada, en el Centro Cultural Alta Córdoba, en mayo de 1983, p. 1.

55 ADEV, "Pablo González Padilla". Folleto de la exposición-presentación desarrollada, en el Centro Cultural Alta Córdoba, en mayo de 1983, p. 1. 


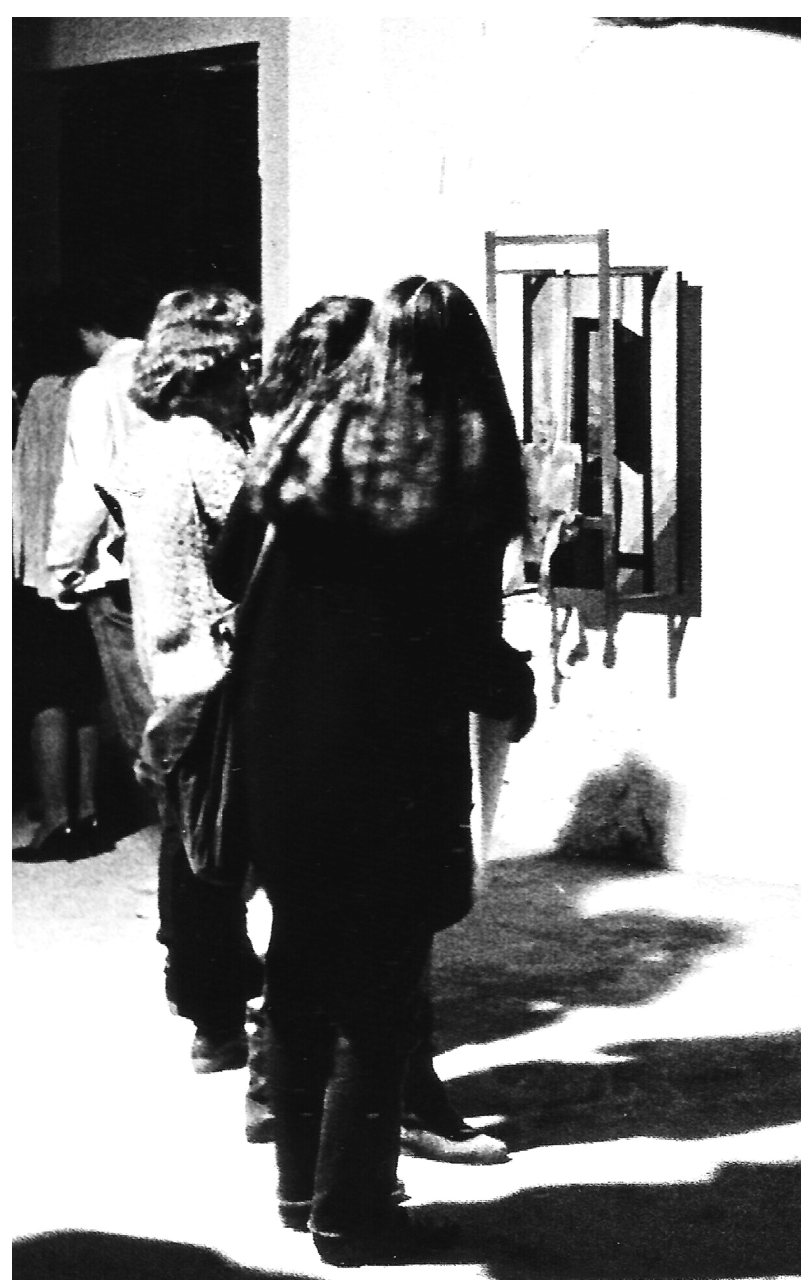

Fig. 8. Avendaño, Hernán. (Idem). Detalle. de incorporar todos los elementos que me sensibilizaron, maderas, metales, luz, color, son parte mía, habitante de ciudad [...]

de abrir puertas en las paredes, buscar la forma de traspasar espacios

en fin, de ser, de compartir, SENTIR CADA MAÑANA UN CIELO DISTINTO, NACER...ESPERAR que sea mañana y CREER ${ }^{56}$.

Esas frases acompañaban la exposición de, al menos, cuatro trabajos; los cuales podemos visualizar a partir de una de las cinco fotografías, resguardadas actualmente, que registraron a las obras de la muestra del CCAC (fig. 7). Inquietando la mirada en las obras de los extremos encontramos figuras humanas alejadas de las tradiciones neoclásicas o realistas, con una experimentación formal que rompía con los criterios espaciales de bidimensionalidad. A la derecha representaciones de senos y pollera aludirían a un cuerpo femenino, el cual era construido sin brazos. Allí, el plano del lienzo evidenciaba una perforación (en el medio de la falda) que dejaba ver una de las maderas del bastidor; conjuntamente, se habían adherido fragmentos sobre el cuadro que otorgaban volumen por encima del nivel del plano. Un detalle de la foto posibilita observar, a la izquierda, como un personaje difuso y su marco traspasaban los límites espaciales del cuadro y retenían la atención de tres espectadores (fig. 8).

Conjuntamente, las fuentes analizadas permiten pensar que la muestra de ADEV en el CCAC expuso la producción de un segundo subgrupo de cuatro integrantes, cuyas propuestas aportaban otros textos literarios y conectaban puentes entre artesanía, cine, escultura, fotografía, instalación, objeto y pintura. Empezando por las obras de Óscar Páez, cabe señalar que la prensa epocal las designaba como Pinturas-objeto ${ }^{57}$.

Centremos e inquietemos la mirada en dos de las cinco fotografías que documentaron las producciones de Páez en aquella exposición colectiva (fig. 9 y 10). Ante esas imágenes es posible interpretar que nos encontramos con una experimentación donde se traspasan y conectan los límites pictóricos y escultóricos. La segunda foto muestra al propio Páez manipulando una de sus obras. Esta podría ser calificada como una especie de construcción enmarcada que ya no se encuentra empotrada en el muro, como en el caso de Avendaño, sino que es situada a una distancia de un metro respecto de la pared ${ }^{58}$. A nivel temático da la impresión de ser una

56 ADEV, "Hernán Avendaño". Folleto de la exposición-presentación desarrollada, en el Centro Cultural Alta Córdoba, en mayo de 1983 , p. 1.

57 "Presentación del grupo ADEV", La Voz del Interior, 26 de mayo de 1983, p. 9.

58 Podemos pensar que esas obras de Avendaño y Páez se reapropiaban de una tendencia difundida en Córdoba desde la segunda mitad del siglo XX: las "pinturas-construcciones" de Marcelo Bonevardi. Moyano destaca que Bonevardi obtiene premiaciones (inter)nacionales desde los años ‘50: "(Buenos Aires, 1929-1994). Desde los 6 años se traslada con su familia a Córdoba [...] En 1958 gana la beca Guggenheim y se va a Nueva York, allí inicia contacto con las obras de Rauschenberg y Nevelson. En 1961 


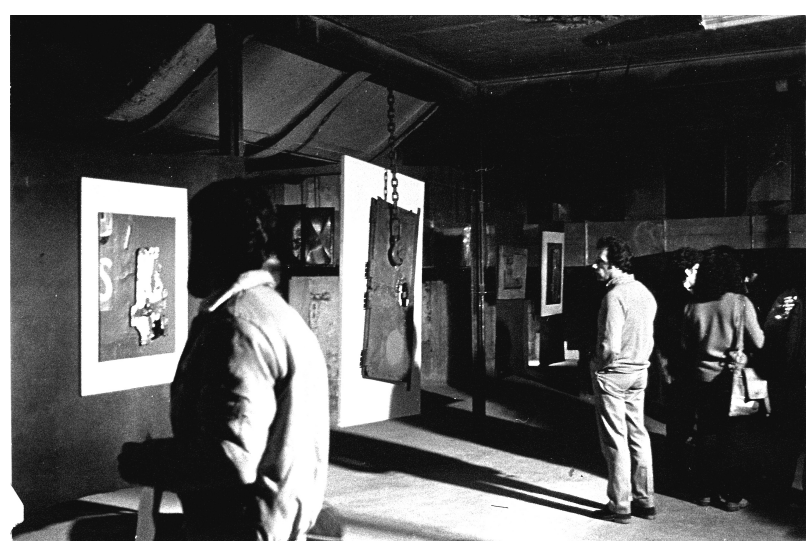

Fig. 9. Páez, Oscar. De la serie Pinturas-objeto, sin datos. Exposición de ADEV en el CCAC, 1983, Córdoba. (Fotografía tomada por Susana Pérez recuperada del Archivo digital de Cáceres).

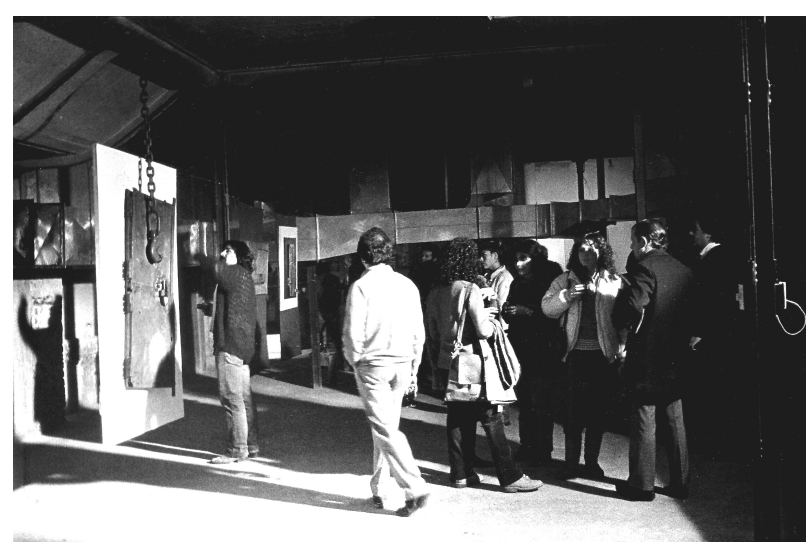

Fig. 10. Páez, Oscar. De la serie Pinturas-objeto, madera y metal, técnica mixta, 170 x $120 \mathrm{~cm}$ (circa). Exposición de ADEV en el CCAC, 1983, Córdoba. (Fotografía tomada por Susana Pérez recuperada del Archivo digital de Cáceres).

puerta reciclada, extraída de su ubicación y función habitual para ser resignificada dentro de un cuadro artístico. Un segundo elemento puede duplicar los interrogantes del espectador: una gran cadena traspasa el marco enlazando al cuadro con el techo, mientras un gancho sostiene y, a la vez, apresa a los restos de la puerta. Una de las integrantes de ADEV, que era novia de Páez en aquellos años, recuerda: "Los materiales principales con los cuales trabajaba Oscar eran metal y madera combinados en técnica mixta" $" 59$.

En su sector del folleto, Páez comenzaba citando una frase de Vasili Kandinsky (1866-1944) donde reverberaban palabras que en aquel 1983 podían adquirir connotaciones extra-artísticas: "Todo lo que está muerto palpita, no sólo en los elementos de la poesía, estrella, luna, bosques, flores, sino aún un botón de calzoncillo, brillando en el barro de la calle. Todo tiene un alma secreta que guarda silencio con más frecuencia que habla"60. En otro fragmento, explicitaba que esa cita del pintor ruso le permitía explicar el punto de partida de su trabajo artístico con materiales en desuso: "el misterio del espíritu de la materia"61.

En cuanto a las obras exhibidas por Anahí Cáceres en el CCAC durante 1983, su testimonio reciente las califica como "objetos abstractos de técnica mixta"62. Otras fuentes posibilitan conocer que esas producciones ya habían circulado por recintos museográficos. Su sitio web permite reseñar los siguientes detalles formales: se trataba de piezas móviles, con medidas aproximadas de 30×30×30 cm, en cuya ejecución habían predominado las técnicas mixtas y los materiales heterogéneos (figs. 11 y 12). Si bien por límites equitativos solo reproducimos aquí dos obras, se invita al lector a consultar la página web de la artista, donde podrá visualizar, entre otras cosas, cinco Objetos móviles ${ }^{63}$ que fueron expuestos en el Museo Municipal de Bellas Artes Dr. Genaro Pérez, en Córdoba, entre 1979 y 1983.

conoce a Joseph Cornell, quien lo orienta en sus pinturas-construcciones". MoYANO, 2010, p. 114. Según los recuerdos de otro entrevistado, que participó como artista invitado en posteriores eventos de ADEV: “durante los años 70 [...] Bonevardi vivía seis meses en Estados Unidos y seis meses en Córdoba”. Entrevista realizada por la autora con Ricardo Castiglia, en Córdoba, el día 16 de mayo de 2009. Sobre estos posibles diálogos convendría seguir investigando.

59 Entrevista realizada por la autora con Anahí Cáceres, en Buenos Aires, el día 3 de noviembre de 2016.

60 ADEV, “Oscar Páez". Folleto de la exposición-presentación desarrollada, en el Centro Cultural Alta Córdoba, en mayo de 1983, p. 2.

61 Ibidem.

62 Entrevista realizada por la autora con Anahí Cáceres, en Buenos Aires, el día 3 de noviembre de 2016.

63 Anahí Cáceres. Obras 1979 - 1987. [en línea], http://www.arteuna.com/PLASTICA/caceresobras0.htm [Consulta: 11 de febrero de 2017]. 

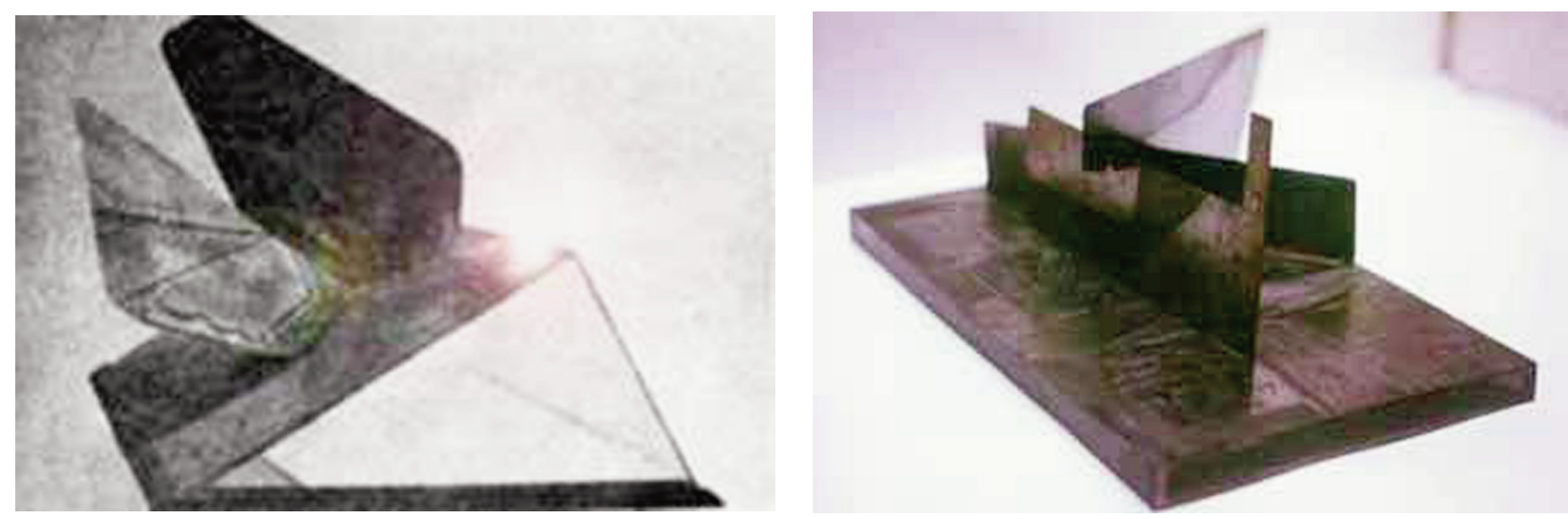

Fig. 11 y 12. Cáceres, Anahí. De la serie Objetos móviles, 1979-1983. Técnica mixta: agua fuerte, aguatinta sobre hierro y bronce; vidrio, espejo, acrílico, madera. 30 x 30 x $30 \mathrm{~cm}$. Obras expuestas en el CCAC, Córdoba, 1983. [En línea], http://www.arteuna.com/PLASTICA/caceresobras0.htm [Consulta: 11 de febrero de 2017]

$\mathrm{Si}$, desde la perspectiva de Didi Huberman, al mirar algunas imágenes estaríamos ante un "montaje de tiempos heterogéneos y discontinuos que forman anacronismos" ${ }^{" 4}$, convendría tener presente que en torno al calificativo de arte objetual se enlazan hilos de sentidos que remiten a diferentes contextos del siglo XX. En Buenos Aires, Herrera detecta una difusión de uno de los herederos de esa corriente, el ensamblado, desde la década de $1970^{65}$. En Córdoba, las fuentes relevadas permiten pensar que fue desde finales de los años 70, y especialmente durante los años 80, cuando el arte objetual se transformó en un género explorado no solo en el circuito alternativo sino también en el ámbito museográfico. Posiblemente, las propias fluctuaciones en las designaciones del año 1983, daban cuenta de tendencias novedosas en torno a las cuales no se había cristalizado una definición. Así, los museos generalmente incluían esas producciones objetuales bajo el título de "esculturas", mientras algunos diarios las calificaban como "construcciones". Este terreno se complejizaba aún más cuando las propuestas abordaban "instalaciones":

Yo había pintado una escalera que iba hacia la nada, había pintado el espacio, había encontrado una puerta, la había pintado y la había puesto como un elemento... Era una instalación. Era una época en que varios grupos empezamos a hacer este tipo de propuestas que eran completamente diferentes a lo que se venía mostrando ${ }^{66}$.

Efectivamente, algunas experiencias visuales de ADEV se localizaban entre las iniciativas pioneras que exploraron, desde Córdoba, la línea de trabajo con objetos e instalaciones ${ }^{67}$. En el folleto de 1983 ciertos fragmentos del texto de Cáceres nos permiten observar algunas estructuras de sentimientos emergentes en sus percepciones sobre el trabajo artístico y sobre la conformación de su propia subjetividad:

El arte no es una mera comunicación o expresión de las experiencias de la vida, es la experiencia misma que tiene como consecuencia vital la transmisión por sí misma. En la obra me encuentro y me hago desde la materia, existo como posibilidad y crezco. Crear es la forma más directa de reconocerme $[\ldots]^{68}$

\footnotetext{
64 Georges Didi-Huberman, Ante el tiempo, Buenos Aires, Adriana Hidalgo, 2008, p. 39.

65 María José Herrera, "Los años setenta y ochenta en el arte argentino", en José Burucúa (dir.) Nueva Historia Argentina. Arte, Sociedad y Politica, Buenos Aires, Sudamericana, 1999, pp. 119-173.

66 Entrevista realizada por la autora con Anahí Cáceres, en Buenos Aires, el día 3 de noviembre de 2016.

67 Otro caso pionero fue la muestra Siete Individuales en 1982.

68 ADEV, "Anahí Cáceres". Folleto de la exposición-presentación desarrollada, en el Centro Cultural Alta Córdoba, en mayo de 1983, p. 1.
} 

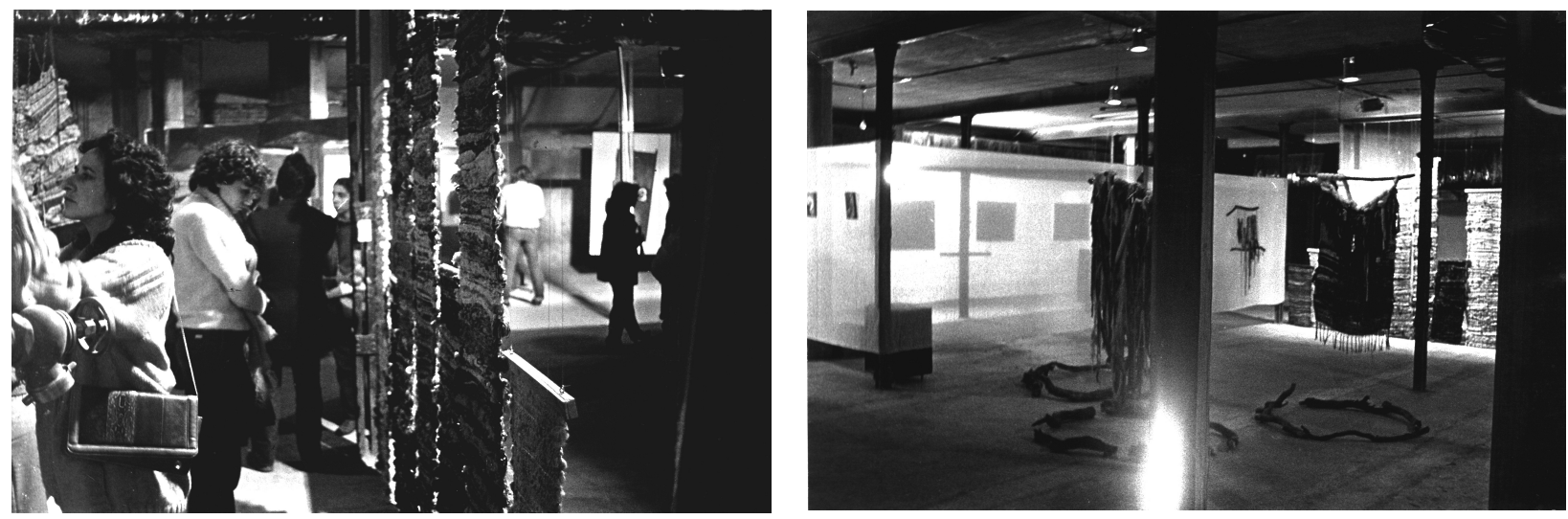

Fig. 13 y 14. Stöck, Patty. De la serie Tapices/Objetos esculturales, 1983. Sin datos. Exposición de ADEV en el CCAC, 1983, Córdoba. (Fotografía tomada por Susana Pérez recuperada del Archivo digital de Cáceres).

Por su parte, las propuestas de Patty Stöck conectaban con una tradición milenaria (la tapicería) que en la segunda mitad del siglo XX había comenzado a ingresar en los museos artísticos de Argentina en general y de Córdoba en particular, discutiendo la frontera entre arte y artesanía ${ }^{69}$. En el folleto de 1983, su texto expresaba, en primera persona, percepciones sobre el tiempo presente, mientras su quehacer era designado no solo como tapices sino como objetos esculturales:

Hoy, Siglo XX, en un rincón de nuestra inmensa Argentina, intento en un esfuerzo continuo de aprendizaje y búsqueda, destacar una vez más, que a través de los continentes y los milenios, siempre está presente [...] el principio de un mismo oficio: una urdimbre de hilos tensos, entre los cuales se mezclan los hilos coloreados de la trama. Hoy las obras que surgen de los telares, nos crean problemas conceptuales acerca de lo que es considerado tradicionalmente como tapicería, pues ya no están destinados a cubrir muros solamente, sino que se nos presentan como objetos esculturales que se suspenden en el centro de las salas [...]

En efecto, en las fotos tomadas por Pérez y resguardadas en el archivo de Cáceres, podemos observar que las obras expuestas por Stöck en el CCAC no estaban colocadas sobre el muro sino instaladas en el espacio, disputando, entre otras cosas, la tridimensionalidad (figs. 13 y 14). El público podía hacer un recorrido alrededor de los tapices suspendidos, distantes del techo y del suelo. A la vez, esta última superficie albergaba objetos que continuaban la obra en el piso. Otro fragmento de su texto de 1983, evidencia que en las palabras de Stöck coexistían tanto la apertura hacia las experiencias transdisciplinares como la (sub)estimación de la posición del "artesano" en relación al "artista":

Tratando de que la artesana que me habita, se eleve a la categoría de artista, me sumerjo desde hace ocho años, en un mar de matices y texturas donde, al jugar con ellos sobre una urdimbre consigo estas, mis humildes obras, en donde pretendo también ahora modificar los principios del material incorporando todo elemento no tradicional que la urdimbre pueda contener, logrando formas que escapan del plano y se unen a la explosión de los últimos años de este fértil campo de la creación ${ }^{70}$.

Finalmente, en uno de los nueve sectores del folleto que formaba parte de la primera exposición de ADEV, Susana Pérez se (auto)definía con fragmentos textuales de su autoría que nos permiten percibir

\footnotetext{
69 En el archivo del Museo Caraffa, se reseña una exposición de 1969 titulada: Joan Wall /Tapices.

70 ADEV, "Patty Stöck". Folleto de la exposición-presentación desarrollada en el Centro Cultural Alta Córdoba, en mayo de
} 1983 , p. 2. 
otras estructuras de sentimiento respecto al trabajo creativo individual y colectivo. Además, si el párrafo firmado grupalmente explicitaba el objetivo compartido de intentar una "comunicación fluida con el espectador”, la oración final de Pérez abría el diálogo hacia posibles valoraciones del público:

[...] Amo ese ser que nos habita, que empuja desde adentro, pasando por sobre todas las pasiones, fluyendo, modificando y creando, para que todas las cosas dejen de ser solo cosas y puedan transmitir todo un mundo de sensaciones que percibo. Trato de reflejar en imágenes la tarea de hombres y mujeres que apasionados por la vida, inmortalizan sus sueños en telas y óleos, fijándolos con cadenas y bronces [...] Dejo a criterio de Uds. mis aciertos y desaciertos en este continuo aprendizaje. ${ }^{71}$

El folleto-cubo registraba una doble participación por parte de Pérez: Fotografía y Film. Otras fuentes históricas permiten conocer que Susana realizó una serie de fotos antes y durante la muestra en el CCAC, de las cuales solo se conservan cinco ejemplares en el archivo de Cáceres. Fue en ese acervo donde obtuvimos las reproducciones analizadas en los casos anteriores. En torno a la situación de la fotografía a comienzos de los años 80, el testimonio de Pérez señala que la misma no tenía un reconocimiento consolidado dentro del campo de las artes visuales de Córdoba ${ }^{72}$. Además, integrando la exposición fundacional de mayo de 1983, Pérez expuso "un cortometraje que documentó [...] la gestación de cada trabajo, el proceso que sigue hasta su maduración" "73. El testimonio de Susana aporta otros detalles: "Hicimos un video [...] Era un registro del armado de la muestra y la muestra funcionando" "74. Triangulando el análisis de diarios, folletos y testimonios, podemos pensar que en la producción y proyección de esa obra audiovisual se anudaron diversos hilos de las prácticas individuales y grupales de ADEV, otro montaje de tiempos heterogéneos y discontinuos que llegó a reproducirse en posteriores eventos de la década de 1980, pero el cual se encuentra perdido en el siglo XXI.

En síntesis, las imágenes y los textos relevados permiten hipotetizar que las "experiencias visuales" de ADEV (re)construían estructuras de sentimientos que daban cuenta de sus complejas vivencias contemporáneas, donde algunos sujetos (tanto los representados en las obras como ciertos artistas y públicos) transitaban la crisis dictatorial "en estados confusos, frágiles e inestables" ". Quedan varios senderos por explorar sobre la historia reciente de la plástica en Córdoba. Por ejemplo, entre los caminos pendientes, más que hablar de monolíticos abandonos de la pintura en los años 60 y retornos en los 80 , sostengo que esa especialidad mantuvo intermitencias variables y jerárquicas entre dichos períodos. Como particularidad de la década de 1980 considero que en esta ciudad mediterránea se atravesaron procesos transdiciplinares cercanos a los corroborados para Buenos Aires, aunque en una escala reducida cuantitativamente en relación a la dimensión de recursos que concentraba la capital del país:

Se trata de una producción plástica multiforme que en ocasiones despliega la elaboración del dolor colectivo tras la tragedia social; ofrece indicios de la experiencia subjetiva frente al nuevo albedrío de las formas; al tiempo que condensa los debates que dentro de las disciplinas artísticas se llevaron adelante [...] a finales del siglo XX. ${ }^{76}$

71 ADEV, "Susana Párez". Folleto de la exposición-presentación desarrollada, en el Centro Cultural Alta Córdoba, en mayo de 1983 , p. 2.

72 Entrevista colectiva realizada por la autora con ex integrantes de ADEV: Anahí Cáceres, Selva Gallegos, Susana Pérez y Jorge Torres. Desarrollada en la Escuela Superior de Bellas Artes "Dr. Figueroa Alcorta”, con apoyo de la Prof. Sara Picconi, en Córdoba, el 22 de octubre de 2015. Un indicador cotejaría esa apreciación: el archivo del Museo Caraffa, registra que recién en 1985 se concretó una muestra dedicada a Fotografía Latinoamericana.

73 "ADEV. Una exposición y una película", La Voz del Interior, 16 de junio de 1983, p. 7.

74 Entrevista colectiva realizada por la autora con ex integrantes de ADEV: Anahí Cáceres, Selva Gallegos, Susana Pérez y Jorge Torres. Desarrollada en la Escuela Superior de Bellas Artes "Dr. Figueroa Alcorta", con apoyo de la Prof. Sara Picconi, en Córdoba, el 22 de octubre de 2015.

75 Usubiaga, 2012, pp. 17-18.

76 Idem. 


\section{Indicios vitales sobre los expositores}

A diferencia de la mayoría de los catálogos que a comienzos de los años 80 visibilizaban datos sobre las trayectorias de los artistas, los dos folletos sobre la muestra del CCAC no aportaban ningún detalle sobre los currículos de los expositores. Sin embargo, podemos encontrar pistas al respecto en textos que historizan a las artes plásticas de los años 1970 y 1980 en Córdoba ${ }^{77}$. Triangulando esos datos con huellas dispersas en variados documentos, es posible bosquejar algunas edades, procedencias, recorridos profesionales y redes locales e (inter)nacionales de los miembros de $\mathrm{ADEV}^{78}$. En la presente sección analizaremos esas variables recorriendo una síntesis de las biografías profesionales de los artistas; las cuales permitirán explorar algunos de los hilos individuales y contextuales que se entrecruzaron en el grupo. ${ }^{79}$

Comenzando alfabéticamente por el subgrupo de cinco productores que, según las fuentes, expuso pinturas, encontramos que Avendaño había nacido en Buenos Aires en 1949, vivía en Córdoba desde la década del 60 y había egresado de la Escuela Provincial de Bellas Artes Figueroa Alcorta (EPBA) en 1982. Entonces, bordeando los 33 años, participó en "la fundación de ADEV". El catálogo grupal de 1984 reseñaba distinciones principalmente pictóricas: 1969, I Premio Mural, Municipalidad de Córdoba; 1970, II Premio Salón de Río Cuarto; 1979, II Premio Grabado, Salón Juvenil de los Artistas Plásticos Asociados de Córdoba (APAC); 1982, I Mención Salón Juvenil de Córdoba ${ }^{80}$. En la entrevista colectiva de 2015, Gallegos recordaba que "Hernán era un artista excelente", mientras Cáceres agregaba: "Trabajaba en IKARenault y consiguió que IKA nos donara sus materiales de desecho"81.

Sobre Gallegos, el Diccionario de artistas plásticos cordobeses, dirigido por Moyano, sintetiza: "Nace en Córdoba, en 1943. Egresa de la EPBA como Profesora de Dibujo y Pintura, y de la Escuela de Artes de la Universidad Nacional de Córdoba (UNC) con los títulos de Licenciada" en las mismas disciplinas. Fue becada por el Fondo Nacional de las Artes y durante 1967-1968 estudió Grabado en L' Ecole de Beaux Arts, de París. Entre sus distinciones, se cuentan: 1970, III Premio en el V Salón Juvenil del MPBA; 1974, II Premio de APAC ${ }^{82}$. El catálogo grupal de 1984 agregaba: "Estudios de Pintura en la Escuela de la Cárcova, Buenos Aires. Directora de la Escuela de Artes Plásticas (UNC) en 1975 y 1976". Para la muestra de ADEV en 1983, Selva bordeaba los 40 años.

González Padilla y La Serna, son citados en el listado de Artistas en preparación que integrarían un futuro Tomo del mencionado Diccionario. También son ubicados en una enumeración no alfabética, de veintiocho hombres y diecisiete mujeres, que "por constituir una generación intermedia -la que sobrellevó el peso de la transición- no siempre ha sido suficientemente reconocida"83. De ambos encontramos una referencia museográfica, a saber: la muestra Arte Joven 83, organizada por el MPBA, los incluía como artistas invitados. En cuanto a La Serna, el catálogo grupal del 84 aportaba datos en primera persona: "Nací

\footnotetext{
77 BlÁzQuez, 2007; Gutnisky, 2006; Moyano, 2010.

78 Fuentes: 1) Arte Joven, Córdoba, MPBA (folletos de muestras anuales 1982 a 1985). 2) Salón Juvenil, Municipalidad de Córdoba (folleto, 1982). 3) Grupo ADEV, Córdoba, MPBA (catálogo, 1984).

79 Esta exploración de trayectorias biográficas sobre artistas de la ciudad de Córdoba pretende contribuir al campo de estudios de la historia de las artes de la última dictadura argentina; en el cual, mientras los relatos escritos sobre y desde Buenos Aires (capital de la República) son mayoritarios, quedan numerosas áreas de vacancia en torno al conocimiento de los agentes y las dinámicas desarrolladas desde otros territorios del país. Para una síntesis sobre avances y lagunas en torno a estudios nacionales de ese período, puede consultarse: Ana LonGONI, "Incitar al debate, a una red de colaboraciones, a otro modo de hacer". Afuera. Estudios de Crítica Cultural, N 13 (2013).

80 Avendaño no figura en el diccionario dirigido por MoYANO, 2010. Si se lo nombra una vez dentro de los veintiocho nombres masculinos que integran el listado de "artistas de la transición” en: GUTNISKY, 2006, p. 102.

81 Entrevista colectiva realizada por la autora con ex integrantes de ADEV: Anahí Cáceres, Selva Gallegos, Susana Pérez y Jorge Torres. Desarrollada en Córdoba, el 22 de octubre de 2015.

82 Moyano, 2010, p. 224.

83 Moyano, 2010, p. 487; Gutnisky, 2006, p. 102.
} 
en 1947 en Córdoba, comencé mis estudios en 1979 en la EPBA. Participé en distintos Salones Nacionales desde 1980". Rondando los 36 años, se incorporó a ADEV.

Sobre Torres, el Diccionario evidencia otros nexos y genealogías: "Nace en Córdoba en 1953 [...] durante sus años como estudiante asiste a talleres de arte en Europa, conociendo la obra del movimiento Cobra y viviendo por algún tiempo en el taller del pintor Antonio Seguí" "84. Documentos cordobeses evidencian que en 1982 Torres participó en el Salón Juvenil municipal, la muestra Arte Joven en el MPBA y la exposición Siete Individuales en el CCGP. Luego, bordeando los 30 años se sumó a ADEV.

En cuanto al segundo subgrupo de cuatro agentes (que en 1983 expuso obras donde se traspasaban las fronteras de artesanía, cine, escultura, fotografía, instalación, objeto y pintura) también percibimos la conformación de diversas trayectorias locales e inter-nacionales. Sobre Cáceres, en el Diccionario se reseña: "Nace en Córdoba en 1953. Vive parte de su infancia en Chile. Cursa desde 1970 a 1973 en la Escuela de Artes de la UNC y expone desde 1974. A partir de ese año, colabora en la Comisión directiva de APAC. En 1982 co-funda el grupo ADEV". Entre sus distinciones, el catálogo de ADEV de 1984 explicitaba: I premio de Grabado en el Salón Juvenil de APAC ${ }^{85}$. En 1981 fue finalista del Concurso de becas del Fondo Nacional de las Artes en investigación de resinas. Rondando los 30 años, participó en la muestra Arte Joven 1982 desplegada en el MPBA.

En cuanto a Páez (Córdoba, 1953-2011), Moyano sintetiza: “De formación autodidacta comienza con su labor plástica a fines de la década de 1970". Ese Diccionario destaca que obtuvo el I Premio en dos eventos de Escultura de 1981: por un lado, el concurso de la Fundación Alejandro Shaw, Academia Nacional de Bellas Artes (Buenos Aires); por otro, el Salón Nacional Villa Constitución (Santa Fe) ${ }^{86}$. Nuestro relevamiento documental permite percibir que, en 1982, sumó otras dos distinciones que lo reconocían como escultor: el II Premio en el Salón Juvenil municipal y la I Mención en el Salón y Premio Ciudad de Córdoba. Promediando los 30 años fue invitado a la muestra Arte Joven organizada por el MPBA en 1982; seguidamente, se sumaría a ADEV.

Con respecto a Susana Pérez y Patty Stöck, no encontramos referencias en los eventos cordobeses de artes plásticas que se multiplicaron entre la última dictadura y el retorno democrático. En cambio, allí sí devino recurrente la presencia de los otros siete integrantes de la agrupación ${ }^{87}$. El catálogo de ADEV de 1984 permite conocer que Pérez había nacido en 1958; además, detalla:

Realizó estudios en la EPBA. Estudió fotografía.

Participó en la Primera Exposición Integral de Fotografía en el Centro Cultural San Vicente. Realizó el catálogo de Marcelo Bonevardi. Efectuó trabajos en fotografía periodística para el diario ‘Acción' de Capital Federal.

En 1982 realiza una exposición individual sobre La Danza, auspiciada por la Municipalidad de Córdoba. Se publica en el diario La Voz del Interior dos páginas con fotografías suyas y textos de Paul Valery El alma y la danza. Realizó dos películas documentales, una de ellas de la ADEV en 1983.

Relacionando esa reseña con la entrevista de 2015, podemos decir que la formación artística de Pérez se vinculaba con el mundo de la fotografía no solo por estudios propios sino por lazos familiares. Era hija de José Anselmo Pérez (1934-), un fotógrafo reconocido en el país y en el exterior desde la década de

\footnotetext{
${ }^{84}$ Recordemos que Seguí (1934-) se había establecido en París durante los años 60, obteniendo consagración internacional. MOYANO, 2010, p. 456.

85 Moyano, 2010, p.138. Entre esos datos, cabe especificar que los Artistas Plásticos Asociados de Córdoba (APAC) remontan su existencia al año 1967, mientras el Salón Juvenil auspiciado por esta asociación, en el cual habrían participado Avendaño y Cáceres, se desplegó entre 1977 y 1981.

86 MoYANo, 2010, p. 355.

87 Tampoco aparecen visibilizadas en los libros de MoYANO, 2010 o GUTNISKY, 2006.
} 
$1960^{88}$. A la vez, la primera muestra individual de Susana en 1982 (una excepción dentro del escaso reconocimento que tenía la fotografía en el campo artístico provincial) dialogaba con otros mundos del arte. Se basaba en tres años de registro en el Ballet Provincial y había sido montada en el Teatro Municipal, mientras sus reproducciones en la prensa fueron acompañadas por fragmentos de un literato francés. Para 1983, la tarea de Susana, quien rondaba los 25 años, establecía dos puentes de contacto con las artes plásticas: por un lado, a partir de la confección de un catálogo para un artista consagrado internacionalmente en los años 60, Marcelo Bonevardi; por otro, mediante una película documental sobre un grupo transdiciplinar de artistas (ADEV), en el cual ella se sumó como integrante.

Las huellas escasas sobre Patty Stöck (Córdoba, 1951-), nos introducen en otros tres mundos de producción cultural: docencia en escuela primaria, psicología y tapices. El catálogo de ADEV de 1984, permite conocer que, cuando se incorporó al "grupo fundador en 1982", bordeaba los 31 años y combinaba diversos recorridos: "Maestra normal y Licenciada en Psicología. Incursiona en técnica de telar a partir de 1976. Participa en muestras colectivas en la Capital Federal en 1978, 1979, 1980”.

Respecto de los dos colaboradores y los dos artistas invitados, que confluyeron en la muestra, queda pendiente la exploración de sus trayectorias y vinculaciones para próximos artículos. Adelantamos que los testimonios de ex integrantes de ADEV asocian la colaboración de Baró y Benavidez con los campos artísticos de música y teatro. En cuanto a los dos invitados, Schneider (1914-2015) y Dujovny (1925-1990), habrían conectado al grupo con "experiencias cinéticas y audiovisuales" de décadas anteriores y de otras instituciones nacionales y extranjeras ${ }^{89}$.

Los datos biográficos relevados sobre los nueve miembros permiten percibir algunas características compartidas que habrían ayudado a la formación del grupo. La mayoría había iniciado sus estudios académicos en las décadas de 1960 y 1970, mientras una minoría optó por aprendizajes autodidactas. Sus titulaciones y premiaciones registraban preponderancias disciplinares (en dibujo, escultura, grabado y pintura); pero sus trayectorias también evidenciaban redes y derivas que los conectaban con otros mundos del arte, tales como: artesanía, cine, fotografía, literatura y música. En 1983, cuando se concretó la presentación pública de ADEV en el campo local, las edades de los "jóvenes" integrantes abarcaban desde los 25 a los 40 años; no obstante, sus invitados posibilitaron diálogos con agentes de otras generaciones que rondaban los 60 y 70 años. Paralelamente, sus obras visuales y literarias daban cuenta de recorridos, tanto materiales como simbólicos, por circuitos y lecturas que los enlazaban con otras ciudades de Argentina y del exterior.

\section{Reflexiones finales}

En el siglo XXI se han concretado valiosos avances en el campo de estudios sobre las prácticas artísticas que formaron parte de la última dictadura en Argentina. Sin embargo, en sintonía con otros países de América Latina, mientras se consolidan las investigaciones organizadas sobre y desde las ciudades capitales, se multiplican las lagunas en torno a los procesos vivenciados en territorios provinciales ${ }^{90}$. Con el pre-

${ }^{88}$ Entre varios vínculos de Anselmo con el mundo de las artes plásticas, se destaca su colaboración, durante los años 60, en los catálogos de la II y III Bienal Americana de Arte en Córdoba. ANÓNIMO, Museo Municipal Genaro Pérez, “Anselmo Pérez”, 26 de abril de 2011 [en línea], https://museogenaroperez.wordpress.com/2011/04/26/anselmo-perez/ [Consulta: 11 de julio de 2016].

89 Sobre el segundo, puede consultarse: Cecilia IRAZustA, "Gregorio Dujovny: el arte cinético como una representación del arte moderno", Avances, n 17 (2010).

90 Los números 13, 15 y 16 de la revista Afuera (disponibles online) ofrecen un muestrario del estado de las investigaciones en torno a prácticas artísticas y culturales emergentes en dictadura y posdictadura en algunos países de Latinoamérica. En Argentina observamos que los estudios historiográficos y curatoriales se encuentran consolidados en Buenos Aires y evidencian desarrollos incipientes en Córdoba y Santa Fe; pero las áreas de vacancia son innumerables en el resto de las provincias. 
sente artículo se intentó contribuir a esos proyectos intelectuales en curso reconstruyendo la emergencia de un grupo artístico (ADEV) cuya formación se produjo, durante el bienio 1982-1983 en Córdoba, tanto en red como en tensión con una política cultural dictatorial que combinaba censuras, fomentos y fisuras.

El análisis de fragmentarias huellas documentales nos permitió explorar algunas características de su conformación. Podemos pensar a ADEV como un grupo abierto que vinculaba diversas generaciones. Si bien la mayoría de miembros eran hombres y mujeres (auto)reconocidos como "jóvenes" nacidos en los años 1940 y 1950, también hubo espacio para invitados masculinos "mayores" provenientes de las décadas de 1910 y 1920. En el equipo confluían fundadores e integrantes inestables junto con participantes y colaboradores esporádicos, quienes procedían de variadas especialidades artísticas. Posiblemente, esas trayectorias dispares les permitieron comenzar a materializar el objetivo que era descripto (y prescripto) en el nombre de la agrupación, es decir, el desarrollo de experiencias visuales.

Entre los factores que posibilitaron la constitución del grupo jugó un rol principal la entidad gubernamental que los albergó, el Centro Cultural Alta Córdoba. Dentro de una política cultural que, desde los inicios del régimen, combinó excepciones, patronazgos y represiones, algunos artistas encontraron en las instituciones resquicios para el asociacionismo, la producción creativa y la libertad de expresión. Ese conjunto de intersticios fue ampliando su potencia durante el agotamiento dictatorial. En ese marco de complejidades, cobra densidad el pedido de un lugar de trabajo efectuado por ADEV al Municipio, la concesión que les hizo la comuna al prestarles el subsuelo del CCAC y la reapropiación que efectuó el grupo de ese sótano, transformándolo primero en taller y luego en sala de exhibición.

En la exposición fundacional de ADEV durante 1983 detectamos la confluencia de nueve integrantes, dos colaboradores y dos invitados. Los datos biográficos sobre los nueve miembros expositores permiten bosquejar algunos de los hilos individuales y contextuales que se entrecruzaron en el grupo. Entre las décadas de 1960 y 1970 comenzaron sus prácticas artísticas (una mayoría cursando estudios académicos y una minoría mediante aprendizajes autodidactas). Para 1983, esos integrantes, cuyas edades abarcaban desde los 25 a los 40 años, se encontraban luchando por el reconocimiento del campo. Sus formaciones y distinciones registraban preponderancias disciplinares bajo titulaciones en dibujo, escultura, grabado y pintura; pero sus producciones evidenciaban lazos que traspasaban las fronteras de esas disciplinas plásticas a la vez que se abrían hacia otros mundos del arte, tales como: artesanía, cine, fotografía, literatura y música. Conjuntamente, los currículos acreditaban circulaciones de sus cuerpos y obras por circuitos de ciudades argentinas (Córdoba, Buenos Aires, Santa Fe) y francesas (París).

En ADEV, la palabra "experiencia" aludía a intercambios individuales y colectivos que favorecían un proceso creativo "libre", donde técnicas, materiales y conceptos "nuevos" cuestionaban "tradiciones" mediante "investigación y experimentación". Todas sus producciones plásticas fueron acompañadas por textos de autoría propia o cita de poetas de otros países (Alemania, Bélgica, Francia, Rusia). Por ejemplo, algunas "experiencias pictóricas" implicaron tanto un distanciamiento del gusto dominante por paisajes neo-impresionistas y figuras humanas idealizadas como la elaboración de críticas simbólicas que abarcaron desde disrupciones plásticas respecto a los cánones del microcosmos hasta denuncias poéticas sobre el "espanto" de "sacrificios" perpetrados por la dictadura en el macrocosmos. A la vez, ciertas "experiencias escultóricas" se alejaron de los materiales "nobles" y de los emplazamientos en pedestales, proponiendo recursos de desecho y objetos instalados que posibilitaban al público reemplazar la tradicional contemplación pasiva por propuestas de recorridos activos.

El análisis de documentos escritos, orales y visuales permite corroborar que, dentro de la urdimbre sistematizada del régimen dictatorial argentino, donde se congregaron militares y civiles en acuerdos explícitos y consensos silenciosos, también emergieron intersticios que habilitaron la libertad de expresión para algunos artistas y públicos. En el ámbito de las artes plásticas de Córdoba, casos como el de ADEV posibilitan observar que, desde lenguajes tradicionales como la pintura hasta géneros emergentes como la instalación, ciertos creadores construyeron obras visuales y escritos poéticos cuyas temáticas, estilos, títulos, 
materiales y montajes proponían existencias disruptivas respecto a los cánones estético-éticos que cimentaban al gusto oficial. Conjuntamente, reconstruían estructuras de sentimientos que daban cuenta de vivencias contemporáneas intensas, a saber: incertidumbre, violencia, confusión, silencio, ausencia, muerte, personajes y ambientes desfigurados y descentrados.

Como cierre y apertura de este artículo, cabe detenernos en un último punto. Luego de concluir la exposición, un periódico local sintetizaba una crítica. Allí, detectamos otras estructuras de sentimientos que conectaban a las obras artísticas con su contexto de producción, la crisis dictatorial. Según el diario: "Los trabajos procuran diversas, pero exigentes aproximaciones a una realidad actual calificada por la distorsión, la angustia o el grito silente" gido, con otras complejidades, en distintos textos elaborados por ADEV. En los mini-manifiestos que integraban su exhibición emergían varios tópicos sobre aquel presente, los cuales podemos analizar, desde los aportes de Agamben, como reflexiones y emociones de "lo contemporáneo" en términos de desfasajes y fracturas entre distintas dimensiones: temporales, espaciales, individuales y colectivas ${ }^{92}$. Así, en los textos de Avendaño y Cáceres reverberaban consideraciones sobre su "hoy"; por ejemplo:

Siento la necesidad [...] de expresarme sinceramente en acuerdo con mi regente sentimiento de estar vivo hoy. Intención urgente de hacer en esta sociedad [...] que parte del sentir que estoy en el punto de partida. (H.A)

La imagen fantasmagórica del tiempo detenido, contrapunto del tiempo real que mueve los lienzos y coloca tonos de polvo sobre el esqueleto de un objeto, que no es otra cosa que el pasado. El tiempo jamás será detenido [...] Pongamos en hora los relojes, que aún es tiempo de equivocarnos; y pensemos que hoy es un minuto, que nosotros somos el instante, que después este rastro será olvido para que podamos entender a dónde vamos. (A.C.) ${ }^{93}$

En la mayoría de los discursos literarios de los integrantes surgía la idea de un cambio contextual que conmocionaba a los sujetos, un presente cargado de un pasado reciente donde, como recitaba la poesía de Gallegos, el "territorio" había sido "laboratorio de genocidio" 94 . A la par, irrumpía la sensación de estar viviendo una época nueva ("la transición democrática" que anunciaban los diarios), la cual habilitaría equivocaciones y donde la función social del arte sería acrecentar la libertad de expresión y de experimentación. En efecto, en diciembre de 1983 Argentina empezaría la recuperación del gobierno democrático. Sin embargo, se abrió una etapa marcada por procesos de distintos ritmos donde los acontecimientos formales del recambio político coexistían con un pathos autoritario de larga duración que permeaba entre otras esferas, a la cultura. Así, en el resto de la década de 1980 se atravesó un período de posdictadura, una coyuntura inestable cuya reconstrucción histórica invita a continuar la indagación de otros hilos y huellas que permitan inquietar la mirada y complejizar el tejido del relato abordando las derivas tanto de ADEV como de otros grupos artísticos ${ }^{95}$.

ALEJANDRA SOLEDAD GONZÁLEZ Doctora en Historia por la Facultad de Filosofía y Humanidades, Universidad Nacional de Córdoba (2013). Se especializa en Historia Cultural del siglo XX, particularmente en pro-

\footnotetext{
91 “ADEV. Una exposición y una película”, La Voz del Interior, 16 de junio de 1983, p. 7.

92 Giorgio Agamben, “¿Qué es lo contemporáneo?”, Desnudez, Buenos Aires, Adriana Hidalgo, 2006, pp. 17-29.

93 ADEV, "Hernán Avendaño" “Anahí Cáceres”. Folleto de la exposición-presentación desarrollada, en el Centro Cultural Alta Córdoba, en mayo de 1983, p. 1.

94 ADEV, "Selva Gallegos". Folleto de la exposición-presentación desarrollada, en el Centro Cultural Alta Córdoba, en mayo de 1983, p. 1.

95 Algunas líneas de investigación en curso respecto a ADEV son las siguientes: (dis)continuidades entre su etapa fundacional (1982-1983), su apogeo (1984) y su disgregación (1985-1986); vínculos entre agentes femeninos y masculinos de distintas generaciones; reapropiaciones de "experiencias" sesentistas y setentistas en configuraciones de los años ochenta; redes artísticas transdisciplinares entre integrantes, colaboradores e invitados; circulaciones y recepciones de estéticas locales y extranjeras; desplazamientos hacia otras ciudades de Argentina, Latinoamérica y Europa.
} 
cesos artísticos y juveniles. Investigadora Adjunta del CONICET. Profesora, por Concurso Nacional, en la Escuela de Historia, FFYH-UNC. Profesora Invitada a postgrados del Departamento de Historia del Arte de la Universidad de Castilla-La Mancha (España, 2014). Dictó clases de posgrado en la Universidad Nacional de la Plata y en la UNC. Desde 2012 es Directora del grupo de investigación: Hacia una Historia Cultural del pasado reciente argentino: artes, juventudes y políticas en la segunda mitad del siglo XX. Córdoba en red (inter)nacional. Radicado en el Centro de Investigaciones de la FFYH y avalado por la Secretaría de Ciencia y Técnica de la UNC. Ha publicado, junto a Verónica. Basile, el libro Juventudes, políticas culturales y prácticas artísticas. Fragmentos históricos sobre la década de 1980. Edit. Alción. Córdoba, 2014. Sus investigaciones pueden consultarse en distintas revistas científicas tanto del país como del exterior: Afuera. Estudios de crítica cultural (Argentina, 2013), European Review of Artistic Studies (Portugal, 2014), Estudios Avanzados (Chile, 2014), ArtCultura (Brasil, 2014), Arte y Sociedad (España, 2015), Nouveau Monde Mondes Nouveaux (Francia, 2016).

Email: alesolegonzalez@gmail.com 